\title{
PRODUCTION REVENUES AND THE INSOLVENT OPERATOR
} W. GRANT BUCHAN-TERRELL*

\begin{abstract}
This paper analyzes the problems a non-operator may suffer in attempting to recover from a receiver or a trustee in bankruptcy monies received by, or paid to, an insolvent operator of an oil and gas project. The contractual relationships which give rise to the issues are reviewed with particular reference to the 1981 Canadian Association of Petroleum Landmen Operating Procedure. An overview of the remedies available to the non-operator in these circumstances is presented, with the principal emphasis upon iracing in equity and at common law. From the uncertainty and shortcomings of these remedies emanates a consideration of new measures to protect the non-operator's position.
\end{abstract}

\section{INTRODUCTION}

\section{A. THE ISSUES}

In the ordinary course of business in the resource industry, the parties to a project appoint one of their number to the position of "operator". The position of operator entails a very broad and of ten exclusive mandate to control and manage the project. It is not unusual for the parties other than the operator (the "non-operators") to assume a minor role in the day-to-day operations of the project, aside from reacting to major proposals. As the operator is usually the owner of a predominant interest in the project with the necessary operating infrastructure and expertise, the delegation of operating functions is efficient and pragmatic.

However, the spectre of industry insolvencies raises many issues as to the precise legal relationship between the operator and the non-operator. The operator handles large amounts of money from, and on behalf of, the non-operators in the usual operating situation. Whether the operator is a fiduciary, an agent, a trustee, an independent contractor, a mere cotenant, or some combination of these roles, the non-operator's right to recover its money or property from the receiver or the trustee in bankruptcy of an insolvent operator is subject to severe limitations. Indeed, it appears that a non-operator can be characterized as nothing more than an unsecured creditor of an insolvent operator. Where the assets of an insolvent operator are inadequate to satisfy the debts of all of its claimants:'

... the claimant who can point to particular property as belonging to him in equity, or mark out a particular fund over which he is entitled to a charge, may recover his claim in full as against the unsecured creditors.

By the time an operator is in the throes of insolvency, the unsecured creditors are probably fortunate to receive a small percentage of their claimed amounts. Therefore, the right or ability to "follow" or "trace" property, including money, in equity or at common law is of critical importance to the non-operator. The application and ef ficacy of the tracing remedies in the context of prevailing operating practice and documentation is a difficult matter. Although tracing in equity, utilizing trust principles, has enjoyed the most attention from scholars, the analysis reveals that tracing at common law may be a superior alternative in certain circumstances.

- Solicitor, Macleod Dixon, Calgary, Alberta.

1. M. Scott, "The Right to 'Trace' at Common Law" (1966-67), U. of Western Australia L. Rev. 463. 
[VOL. XXIII, NO. 1

\section{B. THE APPROACH}

The first step in the analysis will be to consider the rationale for delegating operating duties. The standard agreements which involve the operator/non-operator relationship will then be discussed, and an attempt will be made to characterize the legal roles therein created. Although this portion of the paper is inevitably a penetrating glimpse into the obvious, it constitutes a foundation for the later analysis. Certain of the rights and remedies of the non-operators under such agreements will be then be reviewed in light of the jurisprudence and operational practicalities. Finally, a few suggestions for bettering the precarious position of the non-operator will be submitted with the hope of provoking further debate and innovative responses.

\section{THE ROLE OF OPERATOR}

\section{A. THE DELEGATION RATIONALE}

The practice of one or more parties delegating their operational responsibilities to another party pursuant to the terms of an operating agreement takes place for several reasons:

1. to allow each party to attend to its own operational duties would result in a wasteful duplication of effort and costs;

2. since an oil and gas project of ten involves many parties, chaos would reign if each of the parties did its own accounting and contracting;

3. legal constraints may prohibit a party from assuming an active role in the control and management of the business, for example, a limited partner in a limited partnership;

4. a wide divergence of interests among the parties may necessitate the selection of a go-between to steer a middle course for the group as a whole; and

5. all or some of the parties may lack the expertise or the infrastructure to undertake the operator role.

Correspondingly, the party appointed as operator usually exhibits some or all of the following qualities:

1. it is a majority owner in the project; ${ }^{2}$

2. it is financially healthy; ${ }^{3}$

3. it is a corporation, with the attendant limited liability;

4. it has the expertise and the infrastructure to operate oil and gas projects; and

2. See, e.8. "Canadian Association of Petroleum Landmen Operating Procedure, 1981" (referred to herein as "1981 CAPL"), Clause 202(b)(i), which provides that the Operator shall be replaced it if is also a "Joint-Operator" and ceases to hold or represent at least $10 \%$ of the "participating interests".

3. See, e.8., id. 1981 CAPL, Clause 202(a)(i), which provides that the Operator shall be replaced immediately if it becomes bankrupt or insolvent. The right to replace an operator due to its insolvency is not terribly helpful if the insolvency only becomes known after the receiver arrives and seizes all the bank accounts of the operator. Given the prevailing attitude of corporate comradery in the oil patch, it would be almost unseemly to challenge an operator before a dramatic act of insolvency took place. 
5. it is sufficiently acceptable to the other parties in the project.4

The operator may not be an owner of the project property, but be chosen solely for its special abilities or cost advantages over the owner-parties. ${ }^{3}$

Once appointed, the operator is susceptible to replacement or removal by the parties to the agreement. However, the right to attack the operator is not regularly exercised, nor is it normally exercisable without cause. ${ }^{6}$ Likewise, an operator cannot be challenged on frivolous or unsubstantiated grounds, and the challenging party may be required to assume the operatorship role itself if the incumbent operator is removed, and no other party wishes to assume the operatorship. An unnecessary change of operator can cause much disruption of operations. Non-operators are loathe to attack an operator until the situation is critical. Hence, once appointed, the operator is usually in that position for quite some time.

This cursory review of the delegation function is an introduction to an examination of a few agreements which create the operator/nonoperator relationship in the energy industry:

1. the CAPL Operating Procedure;

2. the "Agent for Seller" type of natural gas purchase contract;

3. the oil sales contract; and

4. the natural gas processing plant construction and operation agreement.

\section{B. THE CAPL OPERATING PROCEDURE}

\section{Overview}

The following examination of agreements will demonstrate that the same pragmatic delegation of responsibilities which facilitates the efficient operation of resource projects also places the non-operator in a position of great financial risk.

The need for an operator typically evolves from successful activities carried out under a farmout, a sublease or a joint exploration agreement. These agreements normally provide that future operations will be governed by the form of operating procedure which is attached to, but not executed concurrently with, the base agreement. The form of operating procedure used extensively in Alberta is the Canadian Association of Petroleum Landmen Operating Procedure ("CAPL"), a form which is periodically revised by a committee of the Canadian Association of

4. See, e.g., supra n. 2, 1981 CAPL, Clause 101(m). The appointment of an operator is generally a pro forma procedure, whereby one party assumes the operatorship by consensus. However, as the magnitude and complexity of operations, and hence the financial stakes, increase, interest in the operatorship heightens. For example. in an offshore exploration project, the parties may hold relatively formal elections to select the operator. and the incumbent operator may be replaced or challenged occasionally.

5. This would more frequently occur in highly technical energy projects, such as a petrochemical project or an extraction plant.

6. See, e.8., supran. 2, 1981 CAPL, Clause 202. 
Petroleum Landmen.7 The CAPL form enjoys wide use because it has been prepared and revised by journeyman practitioners and because it serves the needs of most parties in most projects. Though the CAPL form is sometimes modified to fit a specific project, it will be assumed that the provisions discussed herein remain substantially unaltered in the majority of applications.

Reference will also be made to the standard accounting procedure which is typically attached to the CAPL form, being the accounting procedure recommended by the Petroleum Accountants' Society of Western Canada" ("PASWC').

\section{Specific Provisions}

The position of operator of an oil and gas project under a CAPL form entails a very broad mandate to control and manage the project on behalf of all of the parties. ${ }^{9}$ As Boyer points out in his review of the 1981 CAPL, ${ }^{10}$ the operator is no longer delegated "exclusive" control and management as was the case in the 1971 CAPL and the 1974 CAPL." Under the 1981 CAPL, the operator is required to "consult with the Joint Operators from time to time with respect to decisions to be made" and to "keep the Joint Operators informed with respect to operations planned or conducted". 12 Since the word "consult" can mean anything from consensual decision-making to mere advising, it is unclear whether or not the change in the 1981 CAPL really changes the operator's role.

R. C. Muir neatly summarized the role of the operator as it might be perceived by a strong and competent non-operator: ${ }^{13}$

Generally speaking, under the usual form of operating agreement, the position of the operator is not like that of the old Scottish overseer managing vast tracts of Irish lands

7. The CAPL Operating Procedure originated in 1969 and has been revised three times to date, in the years 1971, 1974 and 1981. Earlier revisions of the Operating Procedure remain in effect. References, therefore, will be made to the "1971 CAPL". "1974 CAPL" and "1981 CAPL", respectively. The first version, produced in 1969, will not be referenced. as it is not in widespread use. Where the 1981 CAPL does not materially differ from the 1971 CAPL or the 1974 CAPL in respect of the relevant provision, reference will be made to the 1981 CAPL only, and specific references to clauses of the CAPL form will be in respect of the 1981 CAPL, uniess otherwise noted. Before 1969, each project generated its own operating agreement, with the concomitant expenditure of time in preparation and. later, in interpretation. See R. M. Boyer, "The 1981 CAPL Operating Procedure" (1983) I A/Ka. L. Rev. 82 for a more comprehensive review of the 1981 CAPL with useful highlights of the changes from the earlier version. See also "CAPL Commentary on CAPL -1981 Operating Procedure" prepared by the Chairman of the CAPL - 1981 Operating Procedures Committee, unpublished.

8. "Petroleum Accountants Society of Western Canada Accounting Procedure, 1983" (referred to herein as "1983 PASWC"). Like the CAPL Operating Procedure, id., the PASWC Accounting Procedure undergoes periodic revision. Since the 1969 and the 1976 versions are substantially similar to the 1983 PASWC for the purposes of this analysis, only the 1983 PASWC is cited in this paper.

9. Supra n. 2. Clause 301. Parties often delegate further responsibilities to the operator beyond the scope of the written operating agreement and, thereby, assume a more passive role.

10. Boyer, supran. 7 at 85.

11. Clause 301 of the 1971 CAPL and the 1974 CAPL provide: "The Operator is hereby delegated the exclusive control and management of the exploration, development and operation of the joint lands for the joint account" [emphasis added].

12. Supran. 2, Clause 301 .

13. Boyer, supran. 7 at 85 to 86, quoting R. C. Muir, infran. 49. 
for absentee owners who have not inspected the lands in three generations. Under operating agreements such freedom as is consistent with the existence of co-ownership should prevail so as to allow each party to pursue his own interests regarding the lands subject to the agreement and adjoining thereto. The operator is merely one of the owners who, for the time being, and subject to the express provisions of the agreement as to supplying information, etc., carries on the routine tasks of hiring contractors to drill wells, lay flow lines and store production. Discussions as to exploitation take place between the parties, subject to voting provisions, as equal co-owners.

However, not all parties see the operator in this way. A non-opertor frequently also grants the operator the exclusive management of the project, as well as allowing it to hold legal title to its project interest. In many projects, there are at least three tiers of parties:

1. the operator, which holds all or an undivided interest in the legal title to the project property;

2. the non-operators, which:

(a) hold undivided beneficial interests in the property and sometimes legal title to their interests,

(b) are parties to the main agreements governing the project, and

(c) are "recognized" by the operator, in that they receive correspondence, notices, authorities for expenditure ("AFE's") and production payments; and

3. those parties which participate through the operator or other parties which are recognized by the operator, but which do not appear on title and are probably not parties to the main agreements relating to the project.

The last category of parties (which are in an inherently more precarious position than the "recognized" parties) will not be explicitly dealt with herein, but their existence as a complicating factor cannot be ignored in practice. It can be assumed that the position of this category of party is worse than that of a "recognized party". Further, a non-operator in a minority interest situation has little potential influence over the conduct or decisions of the operator and the majority interest owners. The passive non-operator is content to "go with the flow", so long as the relationship is functioning.

In exercising its mandate, the operator, among other things, incurs expenses, ${ }^{14}$ acquires and holds real and personal property, ${ }^{15}$ sells petroleum production in certain situations, ${ }^{18}$ receives and distributes revenue, ${ }^{17}$ and keeps the books and records of the project. ${ }^{18}$ Hence, virtually all monies contributed and received by or for the parties flow through the operator

14. Subject to express limits, beyond which all joint ventures must agree in writing: supra $n .2$. Clauses 308, 309, 311, 312, 502, 503 and 902.

15. For convenience, the operator often coordinates the purchase of new properties on behalf of all of the joint venturers. The operator may also hold legal or registered title to all or some of the joint venture property, depending on the number, size, sophistication and degree of active involvement of the joint venturers. This role may not be expressly described in the relevant agreement, but it may arise through the course of dealings. The 1981 CAPL, Clause 207 contains an implied reference to this role. .

16. Supra n. 2 Clause 602. which is subject to Clauses 601 and 603 .

17. Supra n. 2 Clauses 602 and 605 . The 1971 CAPL and 1974 CAPL do not contain a provision equivalent to Clause 605 .

18. Supra n. 2 Clause 305. See also Clauses 310, 501, 503, 504, 701, 702, 703 and 704. 
under the operating agreement. These significant sums of money represent the life blood of the parties, especially those parties which do not enjoy other sources of revenue.

The 1981 CAPL and the 1983 PASWC deal extensively with the structure of operations, ${ }^{19}$ costs and expenses, ${ }^{20}$ duties of the operator ${ }^{21}$ and the relationships of the parties (to which latter subject further comment will be made). 22

Curiously, these agreements touch upon the receipt and disbursement of production revenue in a cursory fashion. ${ }^{23}$ Both the $1981 \mathrm{CAPL}$ and the 1983 PASWC concentrate upon the expenditure side of the operations, including the reimbursement of the operator. ${ }^{24}$ This is curious because one would think that production revenues would be of paramount importance to the parties. Rarely is the protection of substantial sums of money given such short shrift in contemporary commercial documents! It may be that the apparent informality of the 1981 CAPL form and the 1983 PASWC in respect of production revenues is a vestige of the trusting tradition of the Western resource industry. Many a landman has countered a lawyer's title review deficiencies with the response, "Why should we worry? - We're getting paid regularly!". This attitude likely prevails in the area of operational accounting, as well. For that matter, until the recent recession and resulting insolvencies, the oil and gas industry was probably well served by this informal, even casual, approach to the revenue side of operations. Whatever the reasons for the bias of the 1981 CAPL and the 1983 PASWC to the expenditure aspect of operations, it is certain from a legal perspective that the manner in which an operator is allowed to deal with a non-operator's funds places those funds in real jeopardy.

The jeopardy to a non-operator arises from the expressly authorized practice of commingling project funds with other funds of the operator, and the resultant ambiguity of the operator's legal role vis-à-vis the nonoperator. Clause 507 of the.1981 CAPL states:25

19. Supra n. 8 Articles VII, VIII, IX, X, XI, XII, XIII and XVII.

20. Supra n. 2 Clauses 301, 303, 306, 308, 309, 310, 311, 312, 604 and Article V, inter alia. The 1983 PASWC deals almost exclusively with cost and expense accounting.

21. Supra n. 8 Articles II, III, VII and XIV.

22. Supra n. 2 Clauses 302, 303, 307, 1501, 2704, 2801 and Articles XIX. XXIII and XXIV.

23. Supra n. 2 Clauses 305, 310, 501, 507 and Article VI. Note that the 1971 CAPL and 1974 CAPL do not contain a provision equivalent to Clause 605 of the 1981 CAPL. The 1983 PASWC does not even mention production revenues. except by inference in Clause 101(h): "Joint Account means the account showing the charges paid and credits received as a result of the Joint Operators and which are to be shared by the Parties in accordance with the terms of the Agreement (where the "Agreement" means the CAPL form)" [emphasis added]. Clause 102 requires the Operator to break out certain information. "IIIn the event that revenue settlement statements are submitted by the operator . . .". By contrast. the 1981 CAPL and the 1983 PASWC contain numerous protections for the operator with respect to the payment and the advance or reimbursement of costs and expenses. These protections include an operator's lien on production revenue under the 1981 CAPL. Clause 505. See also. 1981 CAPL. Clauses 502, 503 and 506, and the 1983 PASWC. Clauses 102, 103. 104. 105 and 106. The obvious intent of these provisions is to keep the operator whole, so that it does not suffer any liability or expense beyond its share as a co-owner, unless it has breached its duties as operator.

24. Id. esp. Clauses 5.03, S05 and 506.

25. Supra n. 2, Clause 507. 
COMMINGLING OF FUNDS - The Operator may commingle with its own funds the moneys which it receives from or for the account of the Joint-Operators pursuant to this Operating Procedure. (emphasis added)

Surely, no clearer authority to commingle project funds with the general funds of the operator could be devised. Clause 507 apparently authorizes the commingling of amounts paid pursuant to AFE's, ${ }^{28}$ amounts advanced, 27 and also, funds received "for the account of the Joint-Operators". ${ }^{28}$ (The latter funds are presumably derived from the sale by the operator of production owned by the non-operator.)

The effect of Clause 507 is that the operator is expressly authorized to take the funds received from, or on behalf of, the non-operator under the operating agreement and to deposit these funds into its general account, a mixed and amorphous conglomeration of all the funds of the operator. These funds are paid out to the non-operator only if and when required.29 The operator's general account is subject to innumerable receipts and disbursements relating to the given project, to other projects and to the operator's unrelated business transactions. This general account may also be subject to the claims of all of the creditors of the operator if the operator becomes insolvent.

It will be demonstrated later in this paper ${ }^{30}$ that the express authority to commingle project funds on the part of the operator is critical to the characterization of the legal role of the operator and to the availability of effective remedies to the non-operator in the case of an operator insolvency. For the sake of this part of the paper, it is essential to note this express authority to commingle funds, and to proceed to examine other relevant provisions of the CAPL form.

The operator receives project monies in two ways:

1. advances and reimbursements of expenses to be incurred or actually incurred by the operator; ${ }^{31}$ and

2. production revenue receipts. ${ }^{32}$

The operator may also receive government credits, rebates or incentives on behalf of all project participants.

Under a CAPL form, a party may receive "income or proceeds of sale of another party's share of production" and sell another party's share of production if that party "fails or refuses to take in kind and separately dispose of its proportionate share of any production". ${ }^{33}$ The right of a party to take its own share of production in kind is set forth in Clause 601 . Where a non-operator fails to take its share of production in kind, it is reasonable to assume that the operator is generally the party which is

26. Id. Clause 502 .

27. Id. Clause 503.

28. Supran. 25.

29. The Oxford English Dictionary, Vol. I (3rd ed.) defines "commingle" to mean: "to mingle or mix together; to blend" ", and Black's Law Dictionary (Sth ed.) defines the word to mean: "to put together in one mass. e8. to combine funds or properties into common fund or stock".

30. Infra Part IIl.

31. Supra n. 2 Clauses 502,503 and 506.

32. Id. Clauses 602,503 and 605 .

33. Id. Clauses 602 and 603 . 
[VOL. XXIII, NO. 1

selling the other party's share of production and initially receiving the sale proceeds. It will be illustrated below that the interaction of a CAPL form and a production sale agreement is a less than straightforward matter. ${ }^{34}$

The sole obligation imposed upon an operator which is in receipt of production revenues is found in Clause 605 , which reads as follows: ${ }^{35}$

DISTRIBUTION OF PROCEEDS - Subject to the foregoing provisions of this Article, any party that receives income or proceeds from the sale of another party's share of production, shall forthwith distribute such income or proceeds to the party or parties entitled thereto. If a party fails to distribute such income or proceeds within ten (10) days following its receipt. the undistributed amount may, at the option of the party entitled thereto, bear interest (payable by the party holding such income or proceeds for the account of the party entitled thereto) at the rate provided for in Clause 502, from and after the aforesaid ten (10) days until it is paid.

Clause 605 applies only to income or proceeds from the other party's sale of production. It does not apply to any other monies received by one party for another party. Boyer notes that Clause 605 does not enable the operator to set off revenue proceeds against money owing to the operator. This might be regarded as a minor loophole in favour of the non-operator, ${ }^{36}$ although one suspects that in the real world, set-offs are exploited wherever expedient, notwithstanding contractual niceties. Importantly, the 1971 CAPL and the 1974 CAPL do not contain a provision similar to Clause 605 of the 1981 CAPL. Arguably, such a duty to remit income or proceeds would be imposed in equity or at common law even in the absence of an express provision to that ef fect. ${ }^{37}$

Clause 605 imposes a new obligation on the operator (or any other party) in receipt of another's party production revenue, but this provision may do no more than give a non-operator a right of action against the operator for breach of contract. Failure to remit such proceeds will entitle the aggrieved party to exercise its "option" to claim interest (presumably by giving notice to the defaulting party, although the Clause does not so state), but interest on money not paid or not recoverable is still nothing. ${ }^{38}$ The right to interest on unpaid monies may impinge upon the legal characterization of the parties by suggesting that a debtor/creditor relationship exists. Clause 605 does not seem to modify the operator's right to commingle funds of the project with its own funds.

Under Clause 202(b)(ii), the party aggrieved by an operator's breach of Clause 605 (or any other breach) may give written notice to the operator requiring the operator to commence to rectify the default. Failing such action by the operator, it may be replaced, if non-operators representing a majority interest join in the notice. This remedy does not assist in the recovery of the income or proceeds wrongfully retained (or spent) by the operator, or for that matter, in the recovery of funds in the possession of a receiver or a trustee in bankruptcy of the operator.

34. Infra Part II. C and D.

35. Supran. 2.

36. Boyer, supran. 7 at 90.

37. Supran. 1 at 472.

38. When the operator is insolvent, an action for a breach of contract or a claim for interest not paid is somewhat futile. 
Clause 503 is also a new provision which requires the operator to return funds which have been advanced by the parties but which are not currently required. This provision reads, in part: ${ }^{39}$

... Any amounts advanced by a Joint-Operator hereunder and then not required by the Operator for charges to the Joint Account within the time and in the manner proposed, shall be refunded to that Joint-Operator in a prompt and timely manner but in any event prior to the end of the calendar month following the month to which such advance applied, following which any amounts not so refunded may, at that Joint-Operator's option bear interest (payable by the Operator for the account of that Joint-Operator) at the rate provided for in Clause 502, from the day such refund is due until it is paid.

The obligation to refund, and failing a timely refund, to pay interest, applies only to advances made pursuant to Clause 503. No such express obligation to refund applies to other costs and expenses, for example, excess amounts paid under an AFE pursuant to Clauses 701 or 502. Any such excess funds held by the operator may be commingled by the operator pursuant to Clause 507, and paid out to the non-operator in due course, if ever.

Clauses 503 and 605 of the 1981 CAPL do establish two new obligations upon an operator in receipt of another party's money, but it is questionable if either provision substantially improves the non-operator's position in the event of an operator's insolvency. Further, such clauses do not apply to all monies of the project which filter through the operator, as noted above.

\section{The Operator/Non-Operator Relationship}

The 1981 CAPL form goes to some length to define the operator/nonoperator relationship. The key provision is, not surprisingly, entitled "Relationship of Parties" and it reads:40

PARTIES TENANTS IN COMMON - The rights, duties, obligations and liabilities of the parties hereto shall be several and not joint or collective, it being the express purpose and intention of the parties that their interest in the joint lands and in the wells, equipment and property thereon held for the joint account shall be as tenants in common. Nothing herein contained shall be construed as creating a partnership. joint venture or association of any kind or as imposing upon any party any partnership duty, obligation or liability to any other party hereto.

This Clause unequivocally asserts the desire of the parties to operate and co-exist as tenants in common. It expressly negates the joint rights, duties, obligations and liabilities of a partnership. The creation of a partnership, joint venture or association of any kind is also expressly negated, presumably excluding only the relationship of co-tenancy.

Given such an unequivocal statement of intention by the parties in Clause 1501, it would hardly seem necessary to investigate the relationship of the operator/non-operator any further ${ }^{41} \mathrm{Still}$, it is judicious to examine the agreement as a whole, 42 with regard to the provisions appearing both before and after this Clause. ${ }^{43}$

39. Supra n. 2, Clause 503, last sentence.

40. Id. Clause ISOI.

41. 1 Chitty on Contracts (23rd. 1968), 286, para. 609, citing British Movietonews v. London and District Cinemas [1952] A.C. 166 (H.L.).

42. Id. citing Ford v. Beech (1848) $/ 1$ Q.B. 852, 866.

43. Supra n. 41 at 291, para. 620, citing Bartonv. Fitzgerald(1812) 15 East 529, 541 , and Coles v. Hulme (1828) 8 B.\&C. 568 . 


\section{The following definitions are of interest: 44}

"Joint Operator" means a party to the Agreement (the farmout agreement or other contract giving rise to the operating procedurel having a participating interest in the joint lands (including the Operator if it has a participating interest in the joint lands).

"Operator" means the party appointed by the Joint Operators to carry out operations hereunder for the joint account.

"participating interest" means the percentage of undivided interest in the joint lands (or the respective parcels thereof) held by a party as provided in the Agreement.

The definitions anticipate the appointment of an operator which is not a co-owner of the project.

As previously noted, the operator is delegated the "control and management" of the project, subject to an obligation to "consult with the Joint-Operators from time to time" ${ }^{45}$ This role may result in virtually exclusive control, depending upon the conduct of the parties and the version of the CAPL form used. ${ }^{46}$

Except for emergency situations, the operator has limited authority to incur expenses on behalf of the non-operators without an AFE. ${ }^{47}$ Proposed expenditures which would exceed the original AFE amount must be authorized by a supplementary AFE. ${ }^{48}$ This requirement was not included in the 1971 CAPL and the 1974 CAPL.

Clause 302 specifies that "the Operator shall also have all the rights and obligations of a Joint-Operator with respect to its participating interest", thereby reinforcing the view that the operator is merely one of the parties (most likely an owner) which has been delegated certain routine duties. All major operational decisions are subject to the approval of all of the parties or a specified majority thereof. ${ }^{49}$

At first glance, Clause 303 appears to of fer some certainty to the legal characterization of the operator:50

INDEPENDENT STATUS OF OPERATOR - The Operator in its operations hereunder is an Independent Contractor. The Operator shall furnish or cause to be furnished all material, labor and services necessary for the exploration, development and operation of the joint lands. The Operator shall determine the number of employees. their selection and the hours of labor and the compensation for services to be paid them in connection with its operations hereunder. All employees and contractors used in its operations hereunder shall be the employees and contractors of the Operator.

However, it is surmised that this Clause aims to negate the potential vicarious liability of the non-operators for the acts of the operator, which liability would arise if it was determined that the operator was, in fact, an

44. Supra n. 2, Clauses $101(\mathrm{k}), 101(\mathrm{~m})$ and 101(0), respectively.

45. Supra Part II, B, 2, esp. discussion of 1981 CAPL, Clause 301.

46. Id.

47. Supra n. 7. Clause 301 . The limits are: $\$ 25,000$ in the 1981 CAPL. $\$ 10.000$ in the 1974 CAPL and the 1971 CAPL.

48. Supra n. 2. Clause 301.

49. R. C. Muir, "Duties Arising Outside of the Fiduciary Relationship" (1964) 3 Alta. L. Rev. 359 at 365. However, the CAPL form does not expressly provide for a vote on each major discussion. Rather, the CAPL form provides a structure whereby a party can propose an action or decision and the other parties can join in or not as they see fit. subject to the various stipulations and penalties. See, e.g. 1981 CAPL. Clauses 701, 705, 801, 901.902. 903 and Articles X, XI and XII. Clause 102 of the 1969 PASWC requires approval via a specified majority vote. The 1976 and 1983 PASWC do not contain this provision.

50. Supra n. 2. Clause 303. 
employee of the non-operator. ${ }^{51}$ It is dubious whether or not independent contractor status for the operator enhances the recourse of a nonoperator in the case of an operator insolvency. ${ }^{32}$

The non-operator's rights of access to the books and records ${ }^{53}$ and to the operations on the joint lands ${ }^{54}$ are protected, so the operator cannot, in theory at least, isolate the non-operators from the project and the operations (whereas a trustee ${ }^{55}$ or a general partner of a limited partnership ${ }^{\text {so }}$ might lawfully do so, to some extent).

Clause 2301 purports to be a waiver by each party of "any right to apply for any partition of the joint lands or sale thereof in lieu of partition", ${ }^{37}$ a right a tenant in common or a joint tenant would otherwise enjoy. ${ }^{58}$

Clause 2701 provides that, with the exception of the base agreement to which the CAPL form is attached, and then only to the extent that the base agreement is stated to be effective, the operating procedure expressly supersedes all other "agreements, documents, writings and verbal understandings among the parties relating to the joint lands".${ }^{59}$ Clause 2703 provides that no amendment or variation will be ef fective as against any party unless all parties so agree in writing. ${ }^{60}$ Read together, Clauses 2701 and 2703 direct the reader to look only to the CAPL form for all of the terms of the contract between the parties.

The 1983 PASWC contains a schedule of amounts and rates which the operator can charge the non-operators for its services as operator. ${ }^{61}$ These charges reflect a sliding scale percentage of costs, as defined in the 1983 PASWC, and do not appear to incorporate a profit or fee element for the appointed operator. ${ }^{62}$ Thus, the profitability of the operator position depends upon the actual rates inserted into the blanks of Clause 302 of the 1983 PASWC by the parties and upon the efficiency of the operator. The fact that the position of operator is not especially lucrative and requires a minimum level of infrastructure may explain the historical lack of controversy surrounding the appointment of operator in most projects.

51. 2 Chitty on Contracts (24 ed. 1977), para. 2003, and F. M. B. Reynolds and B. J. Davenport. Bowstead on Agency (14th ed. 1976) 12 to 13 and 310-312. See also. 1981 CAPL. Clause 311 and Article IV, respecting insurance and an indemnity in favour of the operator. respectively.

52. Infra Part 1V.

53. Supra n. 2, Clause 30 S.

S4. Id. Clause 307.

55. D. W. M. Waters, Law of Trusts in Canada (1974) 833 to 835 and 43, citing Re Brockbank [1948] Ch. 206.

56. Partnership Act, R.S.A. 1980 c.P-2, as am., ss. 57 and 63.

S7. Supra n. 2, Clause 2301.

58. Law of Property Act, R.S.A. 1980, c.L.8, as am., Part 3, and R. E. Megarry and H. W. R. Wade. The Law of Real Property (4th ed. 1975) 427-428. Quaere whether Clause 2301 effects a contracting out of Part 3 of the Law of Property Act?

59. Supra n. 2, Clause 2701.

60. Id. Clause 2703. This Clause presumably means that any amendments must be in writing.

61. Supra n. 8, Arricle III.

62. The preamble to Clause 320 reads: "Notwithstanding that the actual overhead may be greater or less, Operator shall charge the Joint Account for overhead as follows. . ". 
This review of the 1981 CAPL is not exhaustive of those provisions which may impact upon the relationship of the operator and the nonoperator. Reference must also be made to the main operational articles which describe in detail the procedures and obligations applicable to all operations. ${ }^{\text {B3 }}$

Does this examination of the 1981 CAPL leave any doubt that the operator is merely one of the co-tenants to which specified duties have been delegated? The parties have used general and specific words to express a definite intention. Since this intention (as expressed by Clause 1501 , in particular) does not appear to be contradicted by, or to be inconsistent with, any other provisions of the CAPL form, one would assume that this intention would be honoured by a court. ${ }^{84}$ Contract law is never so simple. As the Oklahoma Supreme Court has stated: ${ }^{65}$

Regardless of what the preliminary negotiations might have been, or what the discussion might have been as to how the property would be acquired and thereafter operated, defendants cannot avoid the fact that they signed written instruments which clearly stated that they are the owners of the property as tenants in common, that they are not partners or mining partners therein, and that said written agreement superseded entirely any other agreement or relationship which might in any way have theretofore existed between the parties ... Defendants cannot be tenants in common and obtain income tax deductions thereby and execute written agreements to that effect so as to allow them to make such deductions, and at the same time be mining partners with plaintiff in order to impose upon plaintiff a fiduciary duty in the acquisition of this property so as to reap an additional financial advantage. They cannot change their legal relationship to plaintiff. at their whim and as it suits their financial advantage of the moment, in derogation of theit written contracts.

There are two reasons to pursue the analysis beyond the words of the 1981 CAPL. First, a court might look behind the express terms of a standard form contract such as the CAPL form, if it is proven that parole evidence should be admitted to determine the true nature of the agreement or the legal relationship of the parties. ${ }^{68}$ Secondly, extrinsic evidence may be adduced to show that the written agreement was not the whole agreement between the parties (although a heavy burden is on the party so asserting in relation to a document which is apparently complete, and in any event, the extrinsic evidence must not be inconsistent with the written terms) ${ }^{67}$ Accordingly, the types of relationships which may be inferred from a CAPL form will be considered in Part III of this paper, after a brief look at a few other typical oil and gas agreements.

\section{c. "AGENT FOR SELLER" GAS PURCHASE CONTRACTS}

The production of natural gas from project lands is sometimes sold to a third party purchaser under a long term gas purchase contract to which all owners are parties. ${ }^{68}$ This situation is to be distinguished from the ex-

63. Supra n. 2. Articles III, VII, VIII, IX, X, XI, XII, XIII and XIV, inter alia.

64. Supra n. 41 at 292, para. 622.

65. Supra n. 49 at 364.

66. Supra n. 41 at 305, para. 655.

67. Id. at 306, para. 659.

68. Prior to the current over-supply situation, gas purchase contracts often had 25 -year terms. The form of contract used as a basis of discussion in this section is a standard form used by a major natural gas purchaser for most of its purchase arrangements in Alberta. New shortterm contracts often contain very similar provisions to those provisions discussed herein. Hence, the distinction between long- and short-term contracts is largely a function of dollars. 
ercise of a party's right under the CAPL form to sell the production of another party which fails to take its share in kind. ${ }^{89}$ That right is revocable by the party which fails to take in kind, at will, "subject to existing sales contracts" and any sales contracts are required to be of a limited duration. ${ }^{70}$ The CAPL form provisions can be regarded as facilitating temporary production sales only.

Under a long term gas purchase contract, each party notionally takes its own share in kind and disposes of it to the purchaser, as each party is entitled to do under Clause 6.01 of the 1981 CAPL. Every owner of the gas is not necessarily a party to the gas purchase contract. This may be due to a multiplicity of parties, or to the relatively small or passive interest of certain parties. The operator is almost always a party, as are most substantial owners, but the operator usually performs a pivotal role in all dealings with the purchaser. Whether acting as a formalized "Agent for Seller" or as an informal agent for an undisclosed principal, which principal is not party to the contract, the operator has de facto control over the production of natural gas from the project wells."

The purchaser is concerned that it is contracting with a party which has the legal right to sell the natural gas, but this concern is usually satisfied by a "by, through and under" kind of representation." The purchaser does not, as a rule, conduct any independent title examination or contract review to verify the selling party's representations respecting its authority to sell the contracted natural gas. ${ }^{73}$ However, the purchaser generally evaluates the deliverability of the natural gas reserves underlying the seller's commitment.

Where one party, probably the operator, contracts with the purchaser to sell another party's gas, only the selling party will receive the proceeds of sale from the purchaser for all gas sold. The non-operators are typically pleased to be selling any gas production and until recently, few attempts were made by the non-operators to sell and dispose of their production independently.

69. Supra n. 2. Clauses 601,602 and 603.

70. Id. Clauses 602 and 603 .

71. As the operator is entitled to do under Clause 601.

72. For example:

Seller in and by these presents does not convey, purport, promise or agree to convey any better title in and to the gas herein contracted for or referred to than the title therein and thereto which Seller now has or to which Seller is entitled in order to produce, process and sell gas from Seller's lands and Seller warrants that it has full right and authority to enter into this Contract and that all such gas is owned and will be maintained by Seller free from liens and adverse claims.

Generally, the contract also includes a "condition" to this effect. It is unclear in contract law whether a breach of such a condition would entitle the purchaser to rescind the contract or whether its only remedy would be in damages.

73. This practice is not unreasonable as it would be costly and time-consuming for a purchaser to do a title review before entering into each gas purchase contract. However. a purchaser of a valuable commodity under a long-term contract should want to be assured that its supply will not be interrupted by adverse claims. Perhaps the purchaser intends to rely on its status as a bona fide purchaser for value without notice. As discussed in Part IV of the text, the purchaser's status as a purchaser without notice may not entitle the purchaser to succeed in an action for conversion or trover. 
Alternatively, each owner of the project production may execute and deliver a gas purchase contract. For the operational convenience of both the purchaser and the sellers, the gas purchase contract of ten provides, at least impliedly, for the appointment of an "Agent for Seller" "74 to act as the agent, with respect to all operational matters, on behalf of all of the sellers. The purchaser does not normally attempt to ascertain the respective shares of each party to the contract, leaving the issue of proper allocation to the Agent for Seller. If the Agent for Seller disappears, literally or financially, the purchaser then must deal with a replacement Agent for Seller, or enter into new contracts with each seller. The agency position under an "Agent for Seller" gas purchase contract carries with it a mandate which may be complementary to the operator's role under the project operating agreement. ${ }^{75}$

The Agent for Seller receives the total proceeds of sale for all sellers each month by way of cheque drawn in the name of the Agent for Seller. ${ }^{70}$ In default of payment by the purchaser, the seller is entitled: (a) to receive interest on the amount due; (b) after a specified period of time.

74. A typical "Agent for Seller" clause reads:

Notwithstanding any of the provisions herein contained, Agent for Seller shall, inter alia. act as agent on behalf of all parties inciuded as Seller, with regard to all operational matters hereunder. Any decisions made by or agreement entered into by Agent for Seller in exercise of the authorization hereby provided for shall be binding upon each party included as Seller. [emphasis added.]

75. As indicated, id., the scope of the agency described in these contracts is extremely broad. Since the gas purchase contract is probably not subject to the terms of the operating agree. ment among the parties, a wise non-operator under a gas purchase contract should limit the authority granted to the Agent for Seller. For example, the non-operators may have a written agreement which requires that any decisions must be voted upon before a decision is communicated to the purchaser.

76. Typical clauses read:

Buyer shall render to Agent for Seller designated pursuant to Section 17.1 hereof, on or before the twenty-fifth (25th) day of each month a statement setting forth the sales volume of gas delivered hereunder by Seller during the preceding month, the MJ content thereof and the total amount payable by Buyer therefor.

and

Buyer agrees to pay Seller on or before the twenty-fifth (25th) day of each month such total amount payable by Buyer for the gas delivered by Seller hereunder during the preceding month. Each such payment shall be made in Canadian funds by cheque drawn in favour of such Agent for Seller. Each such payment and statement under this Section II.I shall be mailed or tendered to such Agent for Seller at its Canadian address as designated by written notice served by Agent for Seller on Buyer. Agent for Seller shall notify Buyer by written notice of any subsequent change in Agent for Seller's Canadian address. 
to suspend deliveries of gas under the contract; and (c) ultimately, to terminate the contract. 7 The gas purchase contract is silent with respect to any rights and remedies of a seller against the Agent for Seller for monies received but not distributed. It is not the duty of the natural gas purchaser to police the obligations (express or implied) of the Agent for Seller to the other sellers. Having signed the gas purchase contract or having allowed its operator or other delegate to do so on its behalf, the seller is dependent upon the Agent for Seller to pass along the benefits (sale proceeds and prepaid gas payments) and to fulfill the obligations of the gas purchase contract.

The "Agent for Seller" gas purchaser contract, therefore, is notable for what it does not contain. Under such a contract, the purchaser does not recognize the respective shares of each seller. The Agent for Seller has no express obligation to hold the sale proceeds in trust for the other sellers. Aside from the scanty provisions relating to the Agent for Seller role, ${ }^{78}$ the contract does not attempt to articulate any further rights or obligations.

It may be noted in passing that these gas purchase contracts can involve huge amounts of money over their long terms. The large lump-sum payments made for prepaid gas (gas paid for, but not taken by the purchaser) fall into the same structure as do other payments under the contract. Hence, the legal relationships and remedies under a gas purchase contract are of great potential financial significance to a non-operator.

It is evident that a non-operator must turn to the operating agreement or to its non-contractual legal remedies for protection in the event of an Agent for Seller defalcation or insolvency. In this connection, the comments in Parts III and IV of this paper will be relevant.

\section{OIL SALES CONTRACTS}

In Alberta, the bulk of oil produced is initially sold to the Alberta Petroleum Marketing Commission (the "APMC"). ${ }^{79}$ Oil produced under Alberta Crown leases must be sold to the APMC pursuant to Alberta

77. Typical clauses read:

If Buyer fails to make each such payment, or any portion thereof, except as provided in Section 11.2 of this Contract, to Seller when same is due, interest thereon shall accrue at the rate of interest which is equal to the prime rate of interest of the Canadian Imperial Bank of Commerce in effect as of the date that such payment is due until the same is paid. and:

If such failure to pay continues for sixty (60) days, Seller, in addition to all other remedies. thereafter may suspend deliveries of gas hereunder and if such default continues for thirty (30) additional days, Seller thereafter may, in addition to any other rights Seller may have. terminate this Contract; provided that in order for Seller to have the right to suspend deliveries or terminate this Contract, Seller must first have notified Buyer in writing fifteen (IS) days prior to exercising either or both of such rights of its intent to do so and give Buyer the right to pay the amount so due to Seller within such fifteen (15) day period.

78. Supran. 74.

79. APMC Annual Report (1982) at S: In the 1981.82 fiscal year the APMC marketed a total of 58.16 billion of petroleum, pentanes plus and bitumen. This total includes the "N.O.R.P." and "S.O.O.P." supplements, discussed infra n. 80. 
legislation and oil produced in Alberta under freehold leases which is entitled to receive the New Oil Reference Price must be sold to the APMC pursuant to a freehold crude oil sales agreement. ${ }^{80}$

\section{The Freehold Oil Sales Agreement}

The APMC freehold crude oil sales agreement (the "APMC Agreement") ${ }^{81}$ bears some resemblance to the private gas purchase contract discussed above, with a few interesting and important differences.

A distinction is made in the APMC Agreement between the "Vendor" (the party which seems to fulfill a role similar to that of the Agent for Seller under certain gas purchase contracts) on the one hand, and the "Owners", being "the owners of the production from the parcels of the said lands separately identified in Schedule " $A$ " and whose ownership percentages are identified in Schedule "A" as to each such parcel" ${ }^{82}$ on the other hand. Thus, in contrast to the Agent for Seller under a gas purchase contract, the APMC has actual notice of each Owner's share of production sold under the APMC Agreement, except those owners whose interests are represented by another party for all purposes under the APMC Agreement.

Secondly, although the Vendor directly receives the total payment from the APMC for all production sold and delivered, ${ }^{83}$ the Vendor is obliged to make timely distributions of the Owner's share of sale proceeds. "As in an "Agent for Seller" gas purchase contract, the Vendor

80. Under the Memorandum of Agreement between the Government of Canada and Alberta dated September 1, 1981, the APMC is directed to administer the New Oil Reference Prict ("N.O.R.P.") and Special Old Oil Price ("S.O.O.P.") in respect of oil produced in Alher. ta. Freehold producers wishing to avail themselves of the N.O.R.P. and S.O.O.P. sup. plements must sell their oil to the APMC. Although some oil is sold privately, private oi sales agreements will not be dealt with in this discussion, because the issues arising unde: such agreements are likely to be similar to those arising under gas purchase contracts discussed in Part II.C.

81. As was the case with the "Agent for Seller" type of gas purchase contract, reference will bc made to a standard form of agreement used by the APMC. Although the specific provi sions of the APMC Agreement are intended to be reasonable examples of current usage. ac tual practice may differ.

82. Clause I(b) of the standard APMC Freehold Crude Oil Sales Agreement states:

"Owners" means the owners of production from the parcels of the sajd lands separatel: identified in Schedule " $A$ " and whose ownership percentages are identified in Schedul. "A" as to each such parcel.

83. Clause 2 of the standard APMC Agreement authorizes the Vendor to deliver the produc tion to the APMC. Clause 4 states:

The Commission shall pay the Vendor for the production from the said lands delivere. hereunder in a month at the category and quality block prices per cubic metre as set forth $i$. the Block Price Schedule in the Price Bulletin in effect for the month. Payments to the Ven dor shall be made by bank transfer or by cheque or draft of the Commission delivered o transferred to the Vendor at its designated bank or at the Vendor's address for servic hereinafter set forth on the twenty-fifth day of the month following the month of deliver! or if the twenty.fifth is not a business day, then on the business day published by the Com mission as payment date for petroleum produced from Crown leases.

84. Clause 5 of the standard APMC Agreement imposes three obligations on the Vendor. on of which is that:

5. (c) The Vendor shall . . . receive from the Commission and make timely distribution o the Owners' shares of sale proceeds. 
warrants its capacity to sell and receive payment for the subject production, and the Vendor indemnifies the APMC against liability arising from any adverse claims in respect thereof. ${ }^{85}$ The APMC Agreement also requires the Vendor to provide an indemnity bond in the event that a claim occurs or that the APMC becomes "apprehensive" of a claim. ${ }^{86}$ Moreover, the APMC Agreement provides that the APMC may require a legal opinion "as to the Vendor's title to production from the said lands and the right to sell and receive payment for the production'. 87

Clause 13 of the APMC Agreement deals with a change of operatorship under the operating agreement (thereby assuming that the Vendor under the APMC Agreement is also the operator of the project, which is a reasonable assumption). The new operator can execute a new APMC Agreement and the existing agreement can then be terminated if the owners so wish.88

Thus, the APMC Agreement expressly deals with the disparate ownership of production and the obligations of the Vendor in a manner not usually encountered in an "Agent for Seller" gas purchase contract. The APMC Agreement exploits the operational convenience of the delegated "Agent for Seller" concept, ${ }^{89}$ while at the same time attempting to afford some degree of protection to the Owners ${ }^{90}$ and to itself. ${ }^{91}$

It appears that the APMC Agreement establishes only an agency relationship. In characterizing the legal role the Vendor vis-a-vis the other Owners, it is noteworthy that the APMC recognizes the share of production owned by each Owner. Part IV of this paper considers whether or

85. By Clause 7 of the standard APMC Agreement:

The Vendor warrants and guarantees that it has the exclusive right to sell and receive pay. meat for production from the said lands that will be delivered for sale to the Commission pursuant to this Agreement.

and by Clause 8:

The Vendor agrees to indemnify the Commission from and against all liability, loss, and save harmless damage, cost or expense which the Commission may hereafter incur, suffer or be required to pay by reason of any adverse claim or claims relating to the Vendor's title to production from the said lands or the Vendor's right ro sell and receive payment for pro. duction delivered hereunder.

86. Clause 9 of the standard APMC Agreement.

87. Clause 10 of the standard APMC Agreement provides:

The Vendor shall within thirty (30) days of recejpt of written request from the Commission provide the Commission with a current title opinion signed by a member of the Law Society of Alberta as to the Vendor's title to production from the said lands and right to sell and receive payment for the production from the said lands.

88. Clause 13 of the standard APMC Agreement provides:

This agreement is not assignable. However, it is not the intention of the parties to preclude by this agreement any change of operator that may occur under an operating agreement made by the Owners of the said lands. If the Vendor ceases to be operator of the said lands or any parcel thereof the Commission may, having regard to the wishes of the Owners, terminate this agreement for the purpose of entering into a new agreement with the new operator.

89. The operational convenience is accomplished by the APMC dealing only with the Vendor. pursuant to Clauses 2, 4 and 11 of the standard APMC Agreement.

90. Clauses I(b). S(c) and 13 of the standard APMC Agreement, supra n. 82, 84 and 88 give the non-operators a degree of protection. However. as the Owners are not parties to the agreement, one wonders who will enforce these provisions.

91. Clauses 7, 8, 9 and 10 of the standard APMC Agreement, supra n. 85, 86 and 87. 
not the APMC Agreement affords the Owners any additional remedies to recover their share of production proceeds from a receiver or trustee in bankruptcy of an insolvent operator.

\section{Crown Lease Oil Sales}

Pursuant to section 21 of the Petroleum Marketing Act, the APMC takes delivery, and sells the lessee's share of petroleum produced from a Crown lease, licence, permit or reservation" as the "exclusive agent" of the owners of the petroleum..$^{93}$ Upon a sale of the oil, the APMC is required to "pay to the owners of it the proceeds of the sale . . within 60 days after the sale". ${ }^{94}$ The APMC thereby assumes part of the role which might otherwise be taken by the operator. ${ }^{95}$

The present provisions were enacted in 1979, at or near the peak of the Alberta energy industry boom. In June of 1983, at what was, perhaps. the bottom of the resources industry recession, the Government of Alberta enacted section 21.1 , which is reproduced in its entirety below: ${ }^{96}$

21.1(1) In this section.

(a) "designated financial institution" means a bank or treasury branch approved by the Commission under subsection (5):

(b) "operator", in relation to any petroleum, means the person who, according to the records of the Commission, is responsible for the delivery of the petroleum to the Commission under this Part on behalf of the owners of the petroleum.

(2) Notwithstanding section 21(1)(c), the Commission may pay any sale proceeds owing by the Commission under section $21(1)(c)$ in respect of petroleum recovered in any month to the operator in relation to that petroleum.

(3) Subject to subsection (4), an operator to whom a payment is made by the Commission pursuant to subsection (2)

(a) is the agent of the owners otherwise entitled to the net sale proceeds under section $21(1)(c)$ for the purposes of receiving those proceeds and paying them to the owners in accordance with this section:

(b) shall keep any proceeds so paid to him separate from other money held by him;

(c) shall hold those proceeds in trust for the owners of the petroleum entitled to receive them; and

(d) shall pay those proceeds to the owners entitled to them within 5 days after receiving them.

(4) An operator is not under a duty to comply with subsection (3)(b) and (c) until the date prescribed by regulation of the Lieutenant Governor in Council as the date on which subsection (3)(b) and (c) come into operation.

(5) An operator may, with the approval of the Commission, designate a bank or treasury branch as a financial institution to whom the Commission may make payments under subsection (6).

(6) Notwithstanding section $21(1)(c)$. the Commission may pay any sale proceeds owing by the Commission under section 21(1)(c) in respect of petroleum recovered in any month to the financial institution designated under subsection (\$) by the operator in relation to that petroleum.

92. In this paper the word "lease" will be used to describe any document of title under which a party is granted the right to explore for and take petroleum and natural gas.

93. Petroleum Marketing Act, R.S.A. 1980, c.P.5, s. $21(1)(a)$.

94. Id. ss. $21(1)(b)$ and (c).

95. Supra n. 2. Clause 605 and text accompanying n. 32 et seq.

96. Supra n. 93, as am. S.A. 1983, c. 40, s. 3, adding s. 21.1. Paragraphs $21.1(3)($ b) and (c) had not been proclaimed in force to August, 1984. 
(7) If the Commission makes a payment pursuant to subsection (6) to a designated financial institution, subsection (3) applies to that institution with respect to that payment as though it were the operator in relation to the petroleum.

(8) A payment by the Commission of sale proceeds to

(a) an operator pursuant to subsection (2), or

(b) a designated financial institution pursuant to subsection (6)

discharges the obligation of the Commission under section $21(1)(c)$ to the owners of the lessee's share of petroleum to the extent of the payment. [emphasis added]

Section 21.1 deserves close examination. Subsections (1), (2) and (8) provide that the APMC is entitled to pay the operator, rather than the owners of the oil as required by subsection $21(1)(c)$, in order to discharge its obligations under subsection $21(1)(c)$. Given the definition of "operator" in subsection 21.1(1)(b), quoted above, it appears that the "person" referred to is not simply the lessee, as there may be several registered lessees on a Crown lease, whereas normally there is only one "operator" .97 The use of the word "person" suggests that the operator need not be a lessee, although this is unlikely. Nothing in the Petroleum Marketing Act or the Regulations specifies how the operator is to be chosen or designated for the purposes of subsection $21.1(1)(b) .{ }^{98}$ One would assume that the operator under the Joint Operating Agreement applicable to the particular lease would be the appropriate party to be the operator for the purposes of the legislation. The operator, however chosen, is subject to the new obligations imposed under subsection 21.1(3).99

Two new obligations now required of an operator are:100

1. to act as the agent of the owners for the purpose of receiving and distributing proceeds for and to the owners; and

2. to pay out sale proceeds to the owners within five days of their receipt.

Subsection 21.1(3)(a) imposes a special agency relationship upon the operator which may or may not have existed before this legislation. Subsection $21.1(3)(d)$ merely obliges the operator to remit sale proceeds

97. Mines and Minerals Act. R.S.A. 1980, c. M-15, s. 135.

98. Subsection $3(1)$ of the Petroleum Marketing Regulation. Alta. Reg. $446 / 81$, enables the APMC to designate the operator "as the agent of the owners":

$3(1)$ For the purpose of carrying out its duties under section $21(1)(c)$ or $32(1)(c)$ of the Act, the Commission may designate the operator of a well, block. project, production spacing unit, unit operation or gas processing plant as the agent of the owners of the lessee's share of petroleum or pentanes plus, as the case may be, recovered from that well, block. project. production spacing unit, unit operation or gas processing plant

(a) to receive from the Commission the proceeds of the sale of that petroleum or pentanes plus, and

(b) to pay those proceeds to those owners.

It may be that an administrative practice has been adopted whereby the party named by the registered lessees as operator will be recognized, so long as such party is itself a registered lessee.

99. Supran. 96.

100. Id. paragraph $21.1(3)(a)$ and (d). 
within a short time after their receipt. ${ }^{101}$ It would appear that subsections $21.1(3)(a)$ and (d) do not fundamentally alter the position of the operator vis-à-vis the non-operators, since the operator, as agent for the nonoperators, is likely obliged in common law to remit sale proceeds within a reasonable time after their receipt. The nature of an agent's obligations in this regard are examined in Part IV of this paper.

No date has yet been prescribed by regulation as the date upon which subsections 21.1(3)(b) and (c) will come into operation. Subsection 21.1(3)(b) will require the operator to hold the sale proceeds "separate from other money held by him"..102 This provision, when proclaimed, will prevent the operator from commingling the sale proceeds received from the APMC with its other funds. This constitutes a clear statutory contradiction of Clause 507 of the.1981 CAPL, discussed above. Similarly, subsection $21.1(3)(c)$, when proclaimed, will require the operator to hold the sale proceeds in trust for the owners. This is a radical departure from the provisions of a 1981 CAPL which negate any relationship other than co-tenancy. ${ }^{103} \mathrm{~A}$ trust can be inferred from the facts of a situation even without express trust language, ${ }^{104}$ but subsection $21.1(3)(c)$ will certainly remove any doubt in the context of oil sales to the APMC.

As demonstrated below, ${ }^{105}$ subsections $21.1(3)(b)$ and (c) will profoundly change the rights and remedies of a non-operator seeking the recovery of its oil sale proceeds from an insolvent operator. Why were such provisions enacted, but not proclaimed by the Government of Alberta?

The enactment was apparently the consequence of several factors. Many companies which had optimistically borrowed heavily in the halcyon times were now insolvent. Although the lenders had not yet decided to "pull the plug", some financial institutions desired to take control over the revenue streams of their high-risk debtors. Previously, the APMC had declined to acknowledge the assignment of APMC proceeds by an operator, or other owner of the proceeds, to a financial institution. Accordingly, financial institutions had been unable to perfect their security on a major source of cash revenue, namely, APMC oil sales proceeds. However, in attempting to accommodate the financial institutions by the enactment of subsections 21.1(5) and (6), the APMC quite correctly recognized that the recipient of APMC proceeds would likely not be

101. The time period preseribed in paragraph $21.1(3)(d)$ should be compared with the sixty days given to the operator to distribute sale proceeds under paragraph $21(1)(d)$ of the Petroleum Marketing Act, supra n. 93, and the ten days given to an operator under Clause 605 of the 1981 CAPL, supran. 2.

102. Note that the paragraph does not specify whether the proceeds from the sale of production under each lease must be kept separate, or whether just APMC oil sale proceeds, generally. must be so kept.

103. Supra n. 40 and accompanying text. But note that Clause 1501 of the 1981 CAPL does not expressly negate a trust obligation. Rather, it declares that the obligations of the parties shall be "several and not joint or collective". Do these words imply that trust obligations are intended to be excluded? Clause 1501 expressly negates "any partnership. duty, obligation or liability" ".

104. Supra $n$. 55 at 47 to 57 , and at 17, as quoted in text accompanying n. 134 infra.

105. Infra Part IV.C. 
the beneficial owner of all such proceeds, and, consequently, that the non-operators required assurance that their proceeds would not be lost in the process. ${ }^{100}$

It appears that subsections $21.1(3)$ and $21.1(7)$ were the means by which the APMC proposed to protect the non-operators' shares of APMC proceeds paid to a financial institution under subsections 21.1(5) and 21.1(6). The need for this protection of non-operators also arises when the APMC proceeds are paid directly to the operator, hence the enactment of subsection 21.1(3). Ironically, the provisions of subsection 21.1(3) appear to have been a beneficial side effect of an effort by the Government of Alberta to upgrade the security position of the lenders to debt-ridden operators. In the final result, the new obligations contained in section 21.1 are somewhat radical, as well as being onerous for either an operator or a financial institution. And that is the probable reason for the non-proclamation of subsections $21.1(3)(b)$ and $21.1(3)(c)$.

The proclamation of subsections $21.1(3)(b)$ and (c) would cause industry operators great consternation because:

1. operators now commingle production revenue with their own general funds. Subsection 21.1(3)(b) would require new and separate bank accounts for Crown lease oil sale proceeds, if not for each project or well with distinct ownership interests. Some additional accounting and administration would be involved, though this burden should be balanced against the importance of protecting the valuable cash flow of the non-operators;

2. operators have enjoyed the use of other parties' money for so long and to such an extent that such funds have become an integral part of the operators' cash flow. There is an ascertainable and substantial monetary benefit to the operator in using other parties' money as a "float" in its own general bank account. 107 The operator saves interest on money it would otherwise be required to borrow, and it earns interest on funds not currently needed by the project; and

3. subsection 21.1(3)(c) mandates a new and onerous role for an operator: the role of trustee. It is highly unlikely that an operator is a trustee for the non-operators in the absence of this provision. ${ }^{108}$

One wonders if the non-operators are cognizant of the salutary ef fects which would result from the implementation of these provisions. Nonoperators would be well-advised to aggressively lobby the Government of Alberta to have subsections $21.1(3)(b)$ and (c) proclaimed in force. ${ }^{109}$

106. Since operators must account for and administer each project and each party therein separately under Clause 305 of the 1981 CAPL, the incremental burden of separate (trust) bank accounts would appear to be moderate. It is submitted, therefore, that the real reasons for operator opposition are reasons 2 and 3 of this list.

107. Boyer, supran. 7 at 89.

108. Infra Part IIl.

109. Such a lobby would logically be carried out by the Independent Petroleum Association of Canada ("IPAC"), which represents the interests of the independent oil and gas participants (as contrasted with the subsidiaries of foreign entities), which constituency would presumably consist mainly of relatively small. non-operator parties. 
Clearly, the financial institutions are reluctant, to say the least, to assume the duties and liabilities of a trustee to the non-operators, ${ }^{110}$ besides the expense and bother of administering the distribution of APMC proceeds.

It is not surprising that subsections $21.1(3)(b)$ and $21.1(3)(c)$ have not been proclaimed. Without such provisions, the financial institutions have had their security position improved at the expense of the non-operators, which could find themselves one step further removed from possession of their share of APMC proceeds."1

It is not known how the APMC is now implementing subsections 21.1(5) and 21.1(6) in the absence of subsections $21.1(3)(b)$ and $21.1(3)(c) .112$

\section{E. GAS PLANT CONSTRUCTION AND OPERATION AGREEMENT}

The gas plant construction and operation agreement (the "C\&O Agreement") is worth examining because operations thereunder are ordinarily regarded as being quite separate from operations under the CAPL form. ${ }^{113}$

The philosophy underlying a C\&O Agreement is that the project is a revenue-generating asset which comprises a distinct business for the owners. The owners of ten express their intention to create a joint venture with each owner holding an individed interest in the whole project. A joint venture agreement is of ten entered into coincidentally with the C\&O Agreement, with the aim of establishing the rights and obligations of the owners, inter se. Strong language is used to negate an inference of a partnership relationship. Another common thread in a C\&O Agreement is that the role of the operator is described in agency and independent contractor language. This language may be quite appropriate in the circumstances, in contrast to the CAPL relationship.

With the evolution of larger and more complex projects has come the "professional" operator which may not be an owner of the project. The "professional" operator is not merely one of the owners to which is delegated some operational duties, as in the CAPL form situation. Rather, the "professional" operator is a highly skilled and well experienced party which may be in the business of operating large projects.

The C\&O Agreement of ten requires the operator to establish a "plant account", through which all plant transactions flow. In addition, there may be a requirement that all cash project monies be directed to a trust

110. Infra Part III. C.

111. Infra Part IV. B.

112. Perhaps the APMC, being aware of the problem, would be willing to impose trust obligations on the financial institution by private agreement.

113. The 1981 CAPL appears to be designed primarily for oil and gas properties which are to be explored, developed and operated (see, inter alia Clauses $101(i),(j),(k)$. (l), (o) and 301. although the word "operations" is not defined), whereas the 1983 PASWC anticipates the operation of a gas plant and other facilities (see, e.g. Clause 302(c)). The form of $C \& O$ Agreement used for the analysis herein probably contains typical provisions. but there is a trend toward specialized agreements. 
account for the benefit of all the plant owners. There may or may not be an express prohibition against the commingling of project funds with any other funds of the operator. ${ }^{114}$

The C\&O Agreement establishes a more formal, detailed and participatory decision-making structure for operations than does the CAPL form. Meetings, committees, voting procedures and decision-making powers are provided for in a relatively precise manner in a C\&O Agreement. The operator normally has no vote or veto as operator. The degree of control retained by the non-operators is proportionate to the complexity of the plant, the relative expertise of the operator vis-à-vis the nonoperators, and the interests of the owners in the project as compared to those of the operator.

Although the basic role of the operator under a C\&O Agreement is analogous to that of an operator under a CAPL form, the C\&O Agreement gives effect to the concept of a distinct business owned by unrelated parties. This significantly improves the position of a non-operator with respect to the safeguarding of monies which are in the hands or control of the operator.

\section{READING BETWEEN THE LINES - THE "TRUE RELATIONSHIP"}

This section surveys the types of relationships which may be inferred from the terms of the agreements examined above or from the conduct of the parties. The relationships surveyed will be co-tenancy, fiduciary, agency and trust. It is understood that these relationships are not mutually exclusive; in fact, some of these relationships frequently exist concurrently. The compartmentalization of co-tenants, fiduciaries, trustees and

114. A prudent C\&O Agreement would provide as follows:

PLANT ACCOUNT: Operator shall set up a Plant Account. All proper costs and expenses incurred hereunder by Operator in connection with construction, operation and maintenance hereunder including Operator's management and administrative overhead charges shall be for the Plant Account.

BASIS OF CHARGES TO OWNERS: (a) Except as otherwise provided in this Agreement. Operator initially shall pay and discharge all costs incurred for the Plant Account. Each Owner shall reimburse Operator for Plant Construction Costs and Plant Operating Costs in proportion to such Owners respective Plant Participation ...

COSTS AND ACCOUNTING PROCEDURE: All authorized costs and expenses of whatsoever kind incurred in the conduct of construction, operation and maintenance under this Agreement shall be borne by the Owners in proportion to their respective Plant Participation at the time such costs and expenses are incurred, except as otherwise expressly provided herein.

'IN TRUST' ACCOUNT: Operator shall set up a separate 'In Trust' account on behalf of the Owners in a Canadian chartered bank or other financial institution approved by the Owners. Operator shall obtain from the chartered bank or other financial institution so selected an acknowledgement to the Owners that the funds held in such 'In Trust' accounts are the property solely of the Owners. All funds received from Owners under this Agreement shall be deposited into this account and disbursements for the Plant will be issued from this account. Funds accruing to this account shall not be commingled with other funds under the control of the Operator. Operator shall provide a monthly reconciliation of said account. Any interest income will accrue to the Owners.

The nature of the funds flowing through a plant account will vary depending upon the relationship of the parties and the structure of the overall project. For example. some C\&O Agreements deai only with plant construction, operation and maintenance, whereas other C\&O Agreements also deal with operating fees, such as processing fees. 
agents is entirely artificial. It is used herein merely to.simplify the analysis of a perplexing area of law. Most cases involving the legal characterization of the parties' roles under an agreement begin with an obvious cotenancy or agency relationship, but conclude with the acceptance or rejection of fiduciary or trust roles by the court. Nor are these roles exhaustive, as non-operators and operators may also be partners, or the operator may be an independent contractor. It is submitted that partnership or independent contractor status does not foster remedies for a nonoperator over and above those of an unsecured creditor. This is partially evidenced by the fact that partners of ten seek out the remedies arising from agency or trust when the defendant is insolvent. ${ }^{115}$

\section{A. THE OPERATOR AS CO-TENANT}

The parties to a CAPL form express a clear intention to be regarded as co-tenants. Further, the parties specifically negate other relationships and obligations. ${ }^{116}$ Megarry and Wade present an excellent summary of the principles of the co-tenancy form of ownership: ${ }^{117}$

1. The tenants hold in undivided shares. Unlike joint tenants, tenants in common hold in undivided shares: each tenant in common has a distinct share in property which has not yet been divided among the co-tenants. Thus tenants in common have quite separate interests: the only fact which brings them into co-ownership is that they both have shares in a single property which has not yet been divided among them. While the tenancy in common lasts, no one can say which of them owns any par. ticular parcel of land.

2. There is no right of survivorship. The size of each tenant's share is fixed once and for all and is not affected by the death of one of his companions. When a tenant in common dies, his interest passes under his will or intestacy, for his undivided share is his to dispose of as he wishes. But rights equivalent to survivorship may be given by express limitation.

3. Only the unity of possession is essential. Although the four unities of a joint tenancy may be present in a tenancy in common, the only unity which is essential is the unity of possession. In particular, it should be noted that the unity of interest may be ab. sent and the tenants may hold unequal interests, so that one tenant in common may be entitled to a one-fifth share and the other to four-fifths, or one may be entitled for life and the other in fee simple.

The vast majority of multi-party operating agreements, production sale agreements and C\&O Agreements specify that the parties hold their interest in undivided shares. ${ }^{118}$ Surprisingly, these forms of agreements normally do not expressly negate a right of survivorship among the parties. Survivorship is less relevant where corporations are involved because corporations do not die. Still, a corporation can be a joint tenant ${ }^{119}$ and resource projects frequently include individuals who can pass away.

115. See, e.g., Henryv. Hammond [1913] 2 K.B. S15 (C.A.).

116. Supra n. 2. Clause 1501 .

117. Supran. 58 at 396.

118. See, e.8., 1981 CAPL, Clauses 101(i), (j), (o) and (r), 302, 1501, 2301, 2801, and Articles 1.1 and XXIV. Unfortunately, however, the CAPL forms are replete with references to " joint ownership". such as "joint tenancy", although "co-tenancy" is apparently intended. With respect to production sale agreements, see Part II.C and D, supra. C\&O Agreements usually create a co-tenancy, dressed in joint venture language.

119. Supra n. 58 at 392. 
There is a presumption of a tenancy in common if the relationship involves an interest in land.120 Perhaps strong indicia of co-tenancy, together with this presumption, are sufficient to negate a joint tenancy'121 and with it, the right of survivorship.

The nature of a party's interest in the project may not create unity of possession with the other owners. An example of this would be the case of royalty holders and net-profits-interest owners. However, the working-interest owners enjoy unity of possession even if one party is delegated the operation function. ${ }^{122}$ That is, each working-interest owner is entitled to hold legal title to its undivided interest in the oil and gas property and to operate such interest even though this right is rarely exercised.

Based upon the wording of the agreements and fundamental property concepts, it is submitted that the parties to a CAPL form, a production sales agreement and a C\&O Agreement are co-tenants, if nothing else.

\section{B. THE OPERATOR AS FIDUCIARY}

The thesis that an oil and gas operator is in a fiduciary role to the nonoperator has been more than adequately considered by numerous and learned practitioners and academics. ${ }^{123}$

Occasionally, it seems that the application of the fiduciary role is extended a little too generously by some commentators, in light of AngloCanadian jurisprudence. ${ }^{124} \mathrm{~A}$ careful reading of the majority and ultimate decisions of the leading Canadian and English cases reveals a deep judicial reluctance to impute a fiduciary role to a party where the

120. Id.

121. Megarry and Wade, supran. 58 , at 393 to 395. describe the four unities of joint tenancy as:

1. Unity of possession (which exists in a co-ienancy);

2. Unity of interest (all tenants hold the same estate, which is often not the case in oil and Bas projects);

3. Unity of title (which is rarely the case in oil and gas projects, although all owners may acquire their interest at the same time and continue to hold such interest); and

4. Unity of time (simultaneous vesting, which is possible, but unusual, in oil and gas projects).

122. As discussed in Part II.B, supra, the operating agreement does not prevent a party from carrying on operation activities. It simply provides a structure within which such actions may be taken: see, e.g., 1981 CAPL, Clause 301 and Articles VII, VIII, IX, X. XI and XII.

123. See, e.g., Boyer, supran. 7 at 85.

124. Midcon Oil \& Gas Led. v. N.B. Dom. Oil Co. [1958] S.C.R. 314, 12 D.L.R. (2d) 705; Act Oils Ltd. v. Pacific Petroleums Ltd. (1975) 60 D.L.R. (3d) 658.677 (Alta. App. Div.); and Great Northern Petroleum and Mines Led. et al. v. Merland Explorations Limited et al. (1983) 25 Alts. L. R. (2d) 67. D. A. MacWilliams, "Fiduciary Relationships in Oil and Gas Joint Venture" (1970) 8 Alla. L. Rev. 233, 234 quotes M. Scott's definition of a fiduciary: "a person who undertakes to act in the interests of another person". Emphasis is often placed on the dissenting S.C.C. judgment and the lower Court judgments in Midcon, id., to find that operators stand in a fiduciary capacity: see, e.8., MacWilliams, id., at 246; E. M. Bredin, Q.C. "Types of Relationship Arising in Oil and Gas Agreements" (1964) 3 Alta. L. Rev. 339 at 341 to 342, cf. Muir, supra n. 49, at 359 to 360 and 363 to 364, where Muir discusses the distinctions to be made between Rand J.'s dissenting judgment in Midcon. id. and conventional practices. American law has also been cited to establish a fiduciary role: see, e.8., Bredin at 347. It is submitted that the U.S. authorities go much further than the Anglo-Canadian law in imputing a fiduciary role in the oil and gas area. See also Fleet $v$. Fleet (1925) 28 O.W.N. 193, 194. 
relevant contract expresses a contrary business intention. A careful reading of these decisions also reveals that the courts are less reluctant to impose additional duties and obligations upon a party if that party is profiting "by reason, and only by reason" of his position, within the meaning of the test enunciated in Regal Ltd. v. Gulliver. ${ }^{125}$ It is quite another thing to impose special duties and obligations upon a party which is performing its role in accordance with the subject agreement. In other words, the Canadian and English courts are more willing to find a fiduciary relationship where a party is profiting from its position in an activity which is not expressly addressed in the relevant contract. Implicit in this approach is a notion of wrongdoing, of one party profiting at the expense of another.

Yet, it is reasonably clear that the fiduciary role may apply to certain aspects of the operator's position. ${ }^{126}$ Relatively little attention has been given to the fiduciary's role in relation to the receipt of another party's money, particularly in the resource industry context.

Shepherd has concisely summarized the fiduciary principle in the Canadian context: 127
1. The law of fiduciaries contains a two step process. The first step is the movement from the proved fact situation to the finding of a duty of loyalty. This step can also be described as the finding of a fiduciary relationship or obligation. The second step is the determination of whether that duty has been breached.
The first step in the analysis, the finding of a duty of loyalty, involves a general legal principle which we have defined as follows:
2. A fiduciary relationship exists whenever any person acquires a power of any type on condition that he also receive with it a duty to utilize that power in the best interests of another, and the recipient of the power uses that power. The essence of this theory of fiduciary relationships is that powers are a species of property. which can be beneficially owned by one person while being exercised by another person, who may be referred to as the legal owner of the power.

The task here is to find a fiduciary relationship between the operator and the non-operator in respect of the monies of the non-operator held by the operator. The express language of the agreement is relevant to the determination of a fiduciary obligation and indeed may be conclusive of the extent of that obligation. ${ }^{128}$ This is true partly because a co-tenancy per se does not involve a fiduciary relationship: ${ }^{129}$

There is no fiduciary relationship between co-tenants of real estate such as will prevent one from buying in for his own benefit; and the mere fact that one co-tenant has been allowed to receive the rents and pay thereout interest and taxes and generally manage the property does not create any such fiduciary relationship: Kennedy v. DeTrafford [1896] I Ch. 762, [1897] A.C. 180; In re Biss [1903] 2 Ch. 40, 57.

It is interesting to note the obiter dicta of Shannon J. in Great Northern Petroleum: ${ }^{130}$

125. [1942] 1 All E.R. 378, 389 (H.L.).

126. Given the powerful position of many operators. and their role vis-a-vis the non-operator's property and money, it is not difficuit to argue a duty of loyalty, at least.

127. J. C. Shepherd. The Law of Fiduciaries (1st ed. 1981) at 35 to 36.

128. Fleet v. Fleet, supra n. 124 at 194.

129. Supran. 127 at 75.

130. Great Northern Petroleum and Mines Lid. et al. v. Merland Explorations Limited et al.. supra n. 124. The judgment does not indicate whether the operating agreement attached to the February, 1972 farmout agreement was a CAPL Operating Procedure. 


\begin{abstract}
It is not disputed that, in some respects, the defendant Meriand owed fiduciary duties to the plaintiff. . . . The defendant's fiduciary duties arose out of a number of contracts between the parties. Under the farmout agreements of 2nd February and 18th August 1972 the defendant Merland, as the operator, was in a fiduciary position with respect to the management and administration of the Westlock Field. Under the gas plant and gathering system agreements, Merland, as the operator, was in a fiduciary position with respect to the management and administration of the gas plant and the gathering system. Pursuant to trust declarations Merland stood as trustee and agent for the plaintiffs ... "in all matters arising under the Gas Purchase Contract relating to the participants' working interest in the lands which are subject to the Gas Purchase Contract".
\end{abstract}

It is somewhat ironic that the courts have, thus far, been reluctant to find a fiduciary relationship when the existence of such relationship is the main issue yet they have been quite willing to do so unequivocally in response to peripheral issues.

The key provisions of the CAPL form in this context are Clauses 301 , $304,507,605$ and 1501. A limited fiduciary obligation on the operator might be inferred from the powers over property granted to the operator by the non-operator. Hence, it is conceivable that a court would hold that an operator owes the non-operator a duty of loyalty in connection with the powers conferred on the operator under a CAPL form.

The provisions of an "Agent for Seller" gas purchase contract, an APMC Agreement and a C\&O Agreement involve the basic elements described in either the Scott or the Shepherd ${ }^{131}$ definitions, in that the operator undertakes to do something for another party (sell production, receive proceeds or build and operate a plant), with the result that the operator surely owes a duty of loyalty at least to remit proceeds or income to the non-operator.

At this point, there appears to be a reasonable argument that the operator in receipt of a non-operator's money under a CAPL form, a production sales contract or a C\&O Agreement, is in a fiduciary relationship with the non-operator. It is necessary to mention that this argument is subject to a major caveat. There is strong authority for the proposition that a party cannot be-in a fiduciary position with respect to another party's money if the first party is not under an express obligation to keep any such money separate from its own money. ${ }^{132}$ Moreover, there is authority for the proposition that even if a party is a fiduciary it can lose that characterization by breaching the terms of its fiduciary role. ${ }^{133}$ In this paper the existence of fiduciary obligations will be regarded as a consequence of a finding of a duty of loyalty.

\title{
C. THE OPERATOR AS TRUSTEE
}

To quote from Waters, the quintessential authority on the Canadian law of trusts: 134

A trust can come into existence in one of two ways. It is either clear from a man's words or acts that he intends to settle property by way of a trust, or the law imposes trust machinery in a given situation to ensure that property passes from one party to another.

131. Supran. 124 at 127.

132. Liquidators of Mercantile Bank and Trust Company Limited et al. v. Credit European S.A. (1980) 32 N.B.R. (2nd) 239. 279 (N.B.Q.B.T.D.): Steffanson v. Jaasma et al. [1976] 4 W.W.R. 449,452 to 453 (B.C.S.C.).

133. In Re Harney Company (1959) Lid. et al. (1963) 4 C.B.R. (N.S.) 71, 76 and 78.

134. Supran. 55 at 17. 
In contrast to some of the commentators, the Canadian courts (especially those of Alberta) have been reluctant to superimpose an express trust on the relationship, created by an operating agreement, between the operator and the non-operator. Sinclair J.A. explained this reluctance in Act Oils Ltd. v. Pacific Petroleums Ltd. as follows: ${ }^{135}$

The question to be decided in this second issue in appeal is whether the learned trial Judge was right in concluding that the fiduciary relationship did not embrace the marketing of the substances. In view of the powerful obligations the law rightly imposes on trustees one is loath to accept such a result unless the arrangements between the parties are clearly in harmony with such a restricted view.

It is submitted that this reluctance to infer a trust role for the operator is justified in view of:

(a) the "powerful obligations" referred to by Sinclair J.A.; and

(b) the intent in the typical operating agreement to negate any obligations other than those of a co-tenancy.

If the parties to a commercial contract intend to impose special and onerous obligations upon one party, surely that party should be aware of these obligations at the time that the contract is entered into.

An analysis of a 1981 CAPL, an "Agent for Seller" gas purchase contract, an APMC Agreement and the Alberta Crown lease oil sales legislation now in force reveals little, if any, basis for finding an "express" trust, as such term is described by Waters. ${ }^{136}$ Subsections $21.1(3)(b)$ and (c) of the Petroleum Marketing Act, which have not yet been proclaimed, will require a statutory trust of sorts for oil sale proceeds from production under Alberta Crown leases. ${ }^{137}$ A C\&O Agreement may include express trust language which makes clear a limited trustee role for the operator of a plant. ${ }^{138}$

The leading cases are strong authority for respecting the expressed intention of the parties. ${ }^{139}$ The alternative approach is to seek the imposition of a constructive trust by operation of law. ${ }^{140}$ The most of ten-quoted American authority on constructive trusts, Scott, has set forth the following "working description" of this type of trust: 141

Where a person holding title to property is subject to an equitable duty to convey it to another on the ground that he would be unjustly enriched if he were permitted to retain it. a constructive trust arises.

135. Act Oils Ltd. v. Pacific Petroleums Lıd., supra n. 124, 677. But note that His Lordship appears to equate the fiduciary role with a role as trustee.

136. Supra n. 55 at 18. Waters discusses the inconsistency in the categorization of trusts. This paper adopts the Waters' categorization which differentiates between "express trusts" and "trusts imposed by operation of law", the latter group including constructive and resulting trusts.

137. Supra Part II.D.2 and see Goodman-Maillot, J. "Deemed Trusts Give Creditors' Claims Undeserved Priority" 25 May 1984 Ontario Lawyers Weekly 7.

138. Supra Part II.E.

139. Supran. 124.

140. A "resulting trust" may also be televant to the operator/non-operator relationship. but. as Waters indicates, supra $\mathrm{n}$. S5, at 17 to 20 , the distinction between a "resulting trust" and a "constructive trust" is not clear.

141. A. W. Scott, "Constructive Trusts" (1955) 7 L. Q. Rev. 39. 
Scott has also defined the constructive trust in the negative:142

1. it does not arise from the intention of the owner of the property. "[it] is imposed regardless of intention";

2. "It]he expressed trustee is under a duty to administer the trust in accordance with its terms; a constructive trustee has no such duty":

3. "[a]n express trust involves a very intensive fiduciary relation, which is lacking in the case of a constructive trust, unless indeed, it arises, as it sometimes does, out of a breach of a fiduciary relation"; and

4. most noteworthy, "a constructive trust, unlike an express trust, is a remedial and not a substantive institution. The court does not give relief because a constructive trust has been created: but the court gives relief because otherwise the defendant would be unjustly enriched; and because the court gives this relief it declares that the defendant is chargeable as a constructive trustee."

The imputation of a constructive trust in order to prevent unjust enrichment occurs with increasing frequency in American law. In contrast, the doctrine of unjust enrichment is scarcely developed in AngloCanadian law. ${ }^{143}$ Also, the degree to which a constructive trust is available as a remedy is quite different in Anglo-Canadian law as compared to U.S. law. ${ }^{14}$ The cautious view is that the constructive trust is not (yet) a remedy to prevent unjust enrichment in Canadian law. Put another way, the Canadian courts are unlikely to impute a constructive trust if the fundamental principles of an implied trust are not in evidence. These distinctions between Canadian and American law should be recognized in any analysis of the availability and efficacy of remedies in a Canadian setting. Moreover, Waters submits, most convincingly, that the unique evolution of the law of constructive trusts in English and Canadian law, as opposed to the development of the restitution remedies in American law, is responsible for the requirement that a fiduciary relationship be proven on the facts before a Canadian court will impose a constructive trust. The roles of fiduciary and constructive trustee are frequently intertwined and co-existent, so that Canadian courts of ten accept or reject both roles concurrently. ${ }^{145}$

Both Waters ${ }^{146}$ and Scott ${ }^{147}$ outline several situations in which a constructive trust has been imposed by the courts in the absence of any trust arising from the intention of the parties, but the only relevant applications appear to be:

142. Id. at 40 to 51 . Waters, supra n. 55 at 333 to 349, discusses the complexities subsumed by Scott's statement of principles.

143. R. Goff and G. Jones, The Law of Restitution (1966) 36 to 37; and supra n. 55 at 334. n. 6.

144. Supra n. 143 at 36 to 37; and supran. 55 at 334:

Though this is obviously a different kind of trust, both in function and source, from the trust arising out of intention, no clear doctrine of constructive trusts has emerged in English law. And, since English case authority has traditionally been followed in Canada, much of the uncertainty in the meaning of the term and the scope of the imposed trust has been brought to Canada. The picture which will emerge is of a term which has been pressed into service for several purposes, connected only in outline with each other, and which is the subject matter of a $800 d$ deal of academic debate. As to the substance of the constructive trust, it will be seen that between England and the United States, there is a fairly considerable difference of opinion concerning its nature or purpose.

But see Petckus v. Becker [1980] 2 S.C.R. 834 which may herald an approach towards the American position.

145. Supran. 124 at 677

146. Supran. 55 at 34010362 .

147. Supran. 141 at 42 to 48. 
1. the "[a]cquisition of property by a fiduciary".(Scott cites numerous specific examples, all of which involve the enrichment of the fiduciary through an abuse of his position, but none of the examples are closely analogous to the operator/non-operator situation); ${ }^{148}$ and

2. the "[a]cquisition through an agreement to hold for others" (unfortunately, Waters only discusses "[o]ral agreements concerning land" and "[j]oint and several wills", neither of which are relevant to the situation in which an operator is in receipt of another party's money). ${ }^{149}$

How does the trust arise in the operator/non-operator situation? If it exists at all, it arises from these facts:

1. the operator receives funds from the non-operator to carry out operations; or

2. the operator sells production from the project lands and receives proceeds from the purchaser of the production. These proceeds relate to the non-operator's share of production, as well as the share of the operator;

3. part of the funds received, or part of the production sold, actually belongs to the non-operator;

4. the operator places the funds into either:

(a) its own general, mixed bank account, or

(b) a separate trust bank account, designated as such for the benefit of the non-operators, in accordance with the terms of the governing agreement;

5. the non-operator expects the operator, within a reasonable period of time, to either:

(a) spend the monies on expenses or property for its benefit and ownership;

(b) return funds advanced but not currently required (1981 CAPL, Clause 5.03]; or

(c) remit its share of production proceeds; and

6. it would be wrong for the operator to apply or retain any such monies for its own benefit and ownership because it does not own such monies.

There is some authority for the existence of a constructive trust on these facts: 150

The case of a tenant in common in possession, and receiving rents for which he is bound to account, is virtually that of a constructive trustee, the other tenants in common being cestuis que trust. [emphasis added]

There are no cases in Anglo-Canadian jurisprudence analogous to the hypothetical facts stated above, and the existing constructive trust cases present a bewildering array of distinctions and seemingly contradictory

148. Supran. 55 at 343: and supran. 141 at 47.

149. Supra n. 55 at 349 10 351 . Scott, supra $n$. 141, at 48, uses the expression "|a|cquisition of property from a fiduciary".

150. McIntosh v. Ont. Bank (1873) Gr. 20 at 33. per Spragge, C.; see also In Re Curry (1898) 2s O.A.R. 267 and Field v. Field(1910) 8 E.L.R. 374 (P.E.I. Chan.). 
principles. Therefore, it is profitable to review those leading Canadian or English cases where the existence of an express or constructive trust was considered on the basis of general principles.

The first statement of general principles is derived from the English case of Henry v. Hammond, which dealt with an express trust on facts not far removed from the instance of an operator selling oil or gas production for a non-operator. A lengthy quote from this leading case is appropriate, both for the facts and the reasoning: ${ }^{131}$

This case raises an interesting point. The question is whether or not the defendant ought to be treated as being in the position of an express trustee in respect of the sum of 961 . 11s. 4d. claimed in this action. This sum is the ultimate balance in his hands upon an account in connection with transactions which he was employed by the plaintiff's firm to carry out in the ordinary course of his business as a shipping agent. The transactions which the defendant was employed to carry out occurred nearly thirty years ago. He is unable to show that he has ever paid this sum over to the plaintiff's firm or to the plaintiff. But for the lapse of time the plaintiff is the proper person to recover it, and he would recover it as a debt due to him in respect of those transactions. Inasmuch, however, as the Statute of Limitations has been pleaded as a defence, he can only recover it by establishing that the defendant is in the position of an express trustee of that sum for him. It is clearly settled that a constructive trust is not sufficient, though I do not think that any question of a constructive trust arises in this case.

A considerable number of authorities have been cited, and the one which has been most often referred to in recent cases is Burdick v. Garrick [L.R. S Ch. 233.]. In that case there is a passage in the judgment of Giffard L.J. which has been referred to with approval by many judges. Lord Macnaghten in Lyell v. Kennedy 114 App. Cas. 437 at 463.I said this: "The principle which governs the case may be stated concisely in the words of the late Lord Justice Giffard. In Burdick v. Garrick [L.R. 5 Ch. at p. 243.] that learned judge expressed himself as follows: 'I do not hesitate to say that where the duty of persons is to receive property, and to hold it for another, and to keep it until it is called for, they cannot discharge themselves from that trust by appealing to the lapse of time. They can only discharge themselves by handing over that property to somebody entitled to it." " The passage there cited from the judgment of Giffard L.J. has also been approved by, among other judges Bowen L.J. in Soar v. Ashwell [[1893] 2 Q.B. 390. at p. 397.], and I think that we may take it as, in the language of Lord Macnaghten. consisely stating the principle which governs this case. We must apply that principle to a case where the property is a sum of money. It is clear that if the terms upon which the person receives the money are that he is bound to keep it separate, either in a bank or elsewhere, and to hand that money so kept as a separate fund to the person entitled to it, then he is a trustee of that money and must hand it over to the person who is his cestui que trust [sic]. If on the other hand he is not bound to keep the money separate, but is entitled to mix it with his own money and deal with it as he pleases, and when called upon to hand over an equivalent sum of money. then, in my opinion, he is not a trustee of the money, but merely a debtor. All the authorities seem to me to be consistent with that statement of the law. I agree with the observation of Bramwell L.J. in New Zealand and Australian Land Co. v. Watson 17 Q.B.D. 374, at p. 382.) when he said that he would be very sorry to see the intricacies and doctrines connected with trusts introduced into commercial transactions. A shipping agent carries on a well understood business. and it cannot possibly be said that he is bound to keep the money of each of the persons by whom he is employed in the course of that business separate. There is not in this case the element that there was in Lyell v. Kennedy [14 App. Cas. 437.] of the moneys [sic] being in fact kept separate. I am aware that if the defendant was bound to keep the money separate, the fact that he did not do so cannot assist him; he has committed a breach of his obligation. The only use of looking at the facts to see whether in the par. ticular case he has kept the money as a separate fund is to see whether he has recognized his obligation. the obligation itself being the essential thing. This principle seems to me to reconcile all the cases.

... Where in such a case a person makes a profit out of the improper use of another person's property, he becomes a trustee of that profit for the owner of the property. 
That case therefore does not assist us in the present one. where there is a mere debt arising out of transactions in respect of property, namely, coals, as to which property no doubt it might possibly be said that the defendant was in a sense a trustee. For instance. he could not have bought the coals himself. He was employed to sell the coals, and to receive the money for them; he was under no obligation to keep the money so received as a separate fund, but he was entitled to mix it with his own moneys [sic], and he was merely a debtor for the amount of the ultimate balance due from him. [footnotes omitted)

In following Henry v. Hammond, supra, Morden J.A. of the Ontario Court of Appeal, in H.E.P.C. Ontario v. Brown summarized the principle as follows: ${ }^{132}$

... where the sole duty of the agent with respect to the money is to pay it to his principal, the relationship between the parties is that of debtor and creditor: Friend v. Young. [1897] 2 Ch. 421; Henry v. Hammond, (supra); and M.A. Hanna Co. v. Provincial Bank of Can., [1935], I D.L.R. S45. S.C.R. 144.

So strict is this principle that in an Ontario case, the Court found evidence that, even though the subject monies were in fact kept separately, no trust existed because the defendant was under no obligation to hold the monies separately from its own funds: ${ }^{153}$

He was under no duty to keep this money separate from his own and the fact that he did

so cannot alter what I find to be the basic relation between the parties. [emphasis added]

This result makes sense in the commercial context, inasmuch as one party to a relationship should not be entitled to alter the agreed relationship unilaterally. There is also authority for the opposite view that a trust need not be communicated to the beneficiaries or be intended by the trustee and the beneficiaries, but this would not appear to be a reasonable proposition in the commercial context, wherein the parties enter into a written contract which deals extensively with the relationship therein created. ${ }^{154}$ It appears that this is not a settled issue in trust law.

It is desirable to repeat another prerequisite to the existence of a constructive trust, namely the existence of a fiduciary relationship. While a court may presume a trust where it finds a fiduciary relationship, or vice versa, the Canadian and English jurisprudence to date illustrates some resistance to the extension of the class of fiduciaries. Accordingly, the inference of a fiduciary role is a real obstacle to be surmounted in the effort to prove a constructive trust.

152. H.E.P.C. Ont. v. Brown [1960] O.R. 91 ; 21 D.L.R. (2d) 551 at 555 (C.A.). Cf. Maralta Oil Co. Lid. v. Industrial Incomes Lid., [1964] 49 W.W.R. 175, 16 D.L.R. (2d) S1I (Alta. C.A.). an express trust case, because a separate account was required and maintained. and because an intention to create a trust was inferred from the subject agreement; Steffanson. supra n. 132 at 450 to 453; Re Hartney, supra n. 133 at 74 to 75 (with respect to amounts paid in excess of the cost of goods purchased - analogous to amounts paid in excess of an A.F.E.?); Re Commonwealth Savings Plan Ltd. (1970) 17 D.L.R. (3d) 34 at SS (B.C.S.C.); Re H.B. Haina and Associates Inc. v. Creditors of H.B. Hajna and Associates, Inc. (1979) 28 C.B.R. (N.S.) 113 at 120 (B.C.S.C.).

153. Commonwealth, id. at 55: Lowden at 11 to 12, which is perhaps distinguishable. because the case holds that in the given situation, there was no debtor-creditor relationship. But the judgment does not state that a trust existed, although H.E.P.C., id.. was disapproved.

154. D. W. M. Waters. "Trusts in the Setting of Business, Commerce. and Bankruptcy" (1983) 21 Alta. L. Rev. 395. 


\section{THE OPERATOR AS AGENT}

\section{General Principles}

Chitty on Contracts describes the creation of agency as follows: ${ }^{155}$

The relationship of principal and agent arises where one party, the principal, consents that the other party, the agent, shall act on his behalf, and the agent consents so to act. . . The consent of the parties may be implied from their conduct and positions with regard to each other ...

The agency relationship is often established and governed by contract, although an "implied agreement" may also be the basis. ${ }^{158}$ Returning to the agreements reviewed earlier, it is a simple exercise to discover expressed and implied agency roles for the operator.

\section{The CAPL Form}

Under a CAPL agreement, the operator is authorized to carry out all manner of actions on behalf of the non-operators under a fairly precise scope of authority. ${ }^{157}$ Throughout the 1981 CAPL, the theme is that of the operator doing acts for the non-operator, as if the non-operator is doing such acts itself. ${ }^{158}$ Of particular interest herein are Clauses 301 and 602, which authorize the operator to incur expenses and to sell another party's production, respectively, and Clause 605 , which requires the operator to distribute production proceeds.

It is submitted that an agency role is not necessarily excluded by Clause 1501. Clause 1501 is primarily concerned with the relationships of all the parties, inter se. The last phrase of the provision, "Nothing herein contained shall be construed . . . as imposing upon any party hereto any partnership duty, obligation or liability to any other party hereto" [emphasis added], can be viewed as merely negating any duty, obligation or liability of a partnership nature. It is, therefore, not difficult to argue that the operator is an agent for each non-operator under a CAPL form.

\section{The Production Sale Agreement}

The "Agent for Seller" gas purchase contract is an agreement wherein the principals consent to the agency role, while at the same time contracting with the third party purchaser. ${ }^{159}$ Unless the project operating agreement also governs the agency role, a great deal must be implied into the gas contract to define the agency relationship. ${ }^{180}$ Contrary to the APMC

155. Chitty on Contracts, supra n. 51 at para. 2002.

is6. Id. para. 2001.

157. Supra Part II.B.2.

158. Non-operators can and sometimes do such acts for themselves. See, inter alia, supra n. 2 1981 CAPL, Articles X, XI and XII. As discussed, supra, in Part II.B.2, the actual degree of control over operations by a non-operator varies with each project.

159. Supra Part II.C.

160. The typical gas contract says very little about the role of the Agent for Seller. It is not clear that an operating agreement would apply to cover this role for the operator. The principles enunciated by Chitty on Contracts, supra n. 51 at paras. 2017 and 2039, suggest that, in the absence of an express term. a Court would look to the conduct of the parties to determine the existence and the scope of the agency. 
[VOL. XXIII, NO. ]

Agreement, the third party purchaser under a gas purchase contract probably does not know the respective shares of each of the seller parties. ${ }^{181}$ In respect of the APMC Agreement, an owner is not a party to the contract, but its respective share of ownership of the production is recognized. ${ }^{182}$ The duties of the "Vendor", as agent, are more fully described than in a gas purchase contract. ${ }^{163}$

The agency relationship in all production sales agreements arises from the desire of the purchaser to minimize its involvement with potentially thousands of producers. Again, it is necessary to ask whether or not the operating agreement overlaps with the production sale agreement. Is the operator taking and selling another party's oil or gas pursuant to Clause 602 ? Is Clause 605, then, applicable to the distribution of the sale proceeds? Is the operator allowed to commingle the sale proceeds under Clause 507? If the operating agreement is not applicable to the sale of production, what agreement governs the sale activity? Perhaps all of the owners are deemed to be parties to the production sale agreement by implication (the implication of a contract between each seller and the purchaser), or by the application of agency principles, whereby each seller is selling its own share of production through the agent. The answers to these questions will vary with the particular facts of each case and will affect the recourse open to the non-operator.

\section{The C\&O Agreement}

Turning now to the C\&O Agreement, a role similar to that of an operator/agent under a $1981 \mathrm{CAPL}$ is found, subject to the distinction mentioned earlier regarding the prohibition against commingling of project funds which is sometimes inserted into these agreements. ${ }^{164}$

\section{Agent as Fiduciary}

It has been said that a fiduciary relationship can occur within any number of other roles, including agency. ${ }^{165}$ It is well established that a fiduciary is often a trustee, although not necessarily. ${ }^{168}$ That a trustee is also a fiduciary is virtually certain.

It also seems that an agent in receipt of its principal's money or property can be a fiduciary, and perhaps, therefore, a trustee by operation of law. 187 Waters sets forth where the two roles of trustee and agency may coincide: ${ }^{108}$

When we turn from express trusts to trusts created by operation of law, however, agency rules do coincide with those of trusts. Every agent who holds office. to which he is appointed by his principal, or who handles property, the title to which may or may not be in himself for the purpose of the agency, may be a trustee by operation of law. This is because the agent occupies a fiduciary role in relation to his principal. The extent of the

161. Supra Part II.C and D.1.

162. Supra Part II.D.1.

163. Supra Part II.C and D.I.

164. Supra Part II.E.

165. Supra n. 127 at 21; Bowstead on Agency (14 ed. 1976) 125.

166. Supran. 55 at 31 and 33; supra n. 127 at 21.

167. Supra n. SS at 44; and Chitty on Contracts, supra n. 51 at para. 2101.

168. Supran. 55 at 45 to 46. 
agent's fiduciary role depends upon the type of agent he is; some agents have a more intimate and trusted role than others. More is expected of a company director, for example, than is expected of a rent collector who is merely required to put those moneys [sic] aside and pay them over at the end of each month.

The agent who has to hand over such profit is a constructive trustee. Can an agent in this position ever be described as an express trustee? The short answer is in the negative because an agent usually has oniy possession, while a trustee has legal title. ...

However, it is essential if the agent is to be an express trustee, or to be made by law a constructive trustee, that there be property which the agent was required to keep separate from his own assets. . . . Otherwise, the agent is a debtor only. [emphasis added]

The conclusion is that a fiduciary/trustee role is inexorably tied to the segregation of the trust property. There can be no "short-cut" via the agency role, because not all agents are fiduciaries or trustees vis-à-vis their principals.

\section{THE REMEDIES}

\section{A. OVERVIEW}

The issue is: "How can a non-operator recover its monies from a receiver or a trustee in bankruptcy of an insolvent operator in priority to the unsecured creditors of the operator, assuming that the remaining assets are insufficient to satisfy all claimants?"

In an operator insolvency, a non-operator commonly faces two situations:

1. a receivership, which is either ongoing or a precursor to final insolvency proceedings, or

2. final bankruptcy, liquidation or a related proceeding.

In both circumstances, the exposure of the non-operator is to the amount of its money then in possession of the insolvent operator.

The non-operator's task will be to prove that a certain amount of money (or property purchased with that money) is actually its money or property, not that of the operator, and accordingly, that such money or property must be returned to it. Alternatively, a non-operator will seek to charge a particular fund from which it is entitled to recover. Success in either endeavour will put the non-operator in a superior position to that of an unsecured creditor of the insolvent operator. This result obtains in all insolvency proceedings, including receivership and bankruptcy. Paragraph 47(a) of the Bankruptcy Act ${ }^{169}$ establishes that property held by the bankrupt in trust for another party is not subject to the distribution of assets under the bankruptcy. An unsecured creditor must seek satisfaction of its claim from the remaining assets of the insolvent operator, which is very likely a futile exercise. The problem for a nonoperator is that the remedies typically available under co-tenancy, agency or contract actions are inadequate to promote the non-operator to secured creditor or trust beneficiary status, or the equivalent. These kinds of actions generally constitute actions in personam, or actions against the insolvent party personally. Given the insolvency of the defendant, the plaintiff's action is doomed to failure from the start. 
What follows is by no means an exhaustive or thorough examination of the remedies. Rather, this paper highlights the non-operator's potential remedies under two branches of law:

1. tracing in equity; and

2. following at common law.

As this is an overview of certain remedies, no procedural aspects will be discussed. A proper analysis of the procedural aspects of these remedies would easily justify a separate paper.

\section{B. THE PROPRIETARY REMEDIES}

\section{Introduction}

Tracing in equity and following at common law are both doctrines which may lead to proprietary claims, as distinguished from personal claims, such as an action for money had and received. Proprietary claims are described as claims in rem, or against the world, whereas personal actions, or claims in personam, are claims against persons (in the widest sense). However, such demarcation of proprietary remedies and personal claims is misleading, as the issue is far from being resolved so neatly. ${ }^{170}$

A proprietary claim is reputed to have several advantages over a personal claim:

1. priority over unsecured creditors may be obtained;

2. the claimed money or property may have gone into the hands of an innocent third party, so that a personal claim is of no avail;

3. a successful proprietary claimant can obtain an order for the preservation of the property pending trial; ${ }^{171}$

4. a successful proprietary claimant may be entitled to recover the "fruits" of the property which have accrued while the property was in the defendant's hands; ${ }^{172}$ and

5. the only remedy available to a plaintiff may be a proprietary one due to technical bars to the personal claim. ${ }^{173}$

The supposed advantages of a proprietary claim should not be accepted at face value, because it is difficult to locate clear and consistent applications of the proprietary remedy principles.

The essence of a proprietary claim is aptly summed up by Waters: ${ }^{174}$

The nature of the proprietary remedy should be fairly simple to state. What the law in England and Canada has been striving to attain is a general remedy giving restitution to any person who can show that property in which he has a right of, or to, ownership, is in another's hands, whether in its original or in a converted form. Such a recovery action would require that there be property to be followed (as opposed to a disguised personal claim), and that such property remain capable of identification in the sense that its physical or notional existence can still be earmarked. In the interests of the security of

170. Supra n. 55 at 879,882 and supran. 143 at 34, 35. Scott, supra n. I appears to disagree. See also. D. W. M. Waters, "The Nature of the Trust Beneficiary's Interest" (1967) XLV Can. Bar Rev. 219.

171. Supran. 143 at 34 .

172. Id.

173. Id. at 479. Note that the right of following at common law is probably an action in rem. though the actions based thereon are in personam.

174. Supran. 55 at 880. 
commercial transactions and of titles, the remedy would cease to be avajiable once the property gets into the hands of a bona fide purchaser for value without notice, at the time of the transaction, of the outstanding claim. An innocent third party donee of the property would be required to surrender it, however, unless he could show that he changed his position in reliance upon the gift, and that it would prejudice him unfairly to deprive him of the property. What would constitute a change of position would be essentially a question of fact in each case, and therefore be a defence within the court's discretion.

Tracing is not a remedy. It is a right which creates the remedy to recover the traced property. ${ }^{173}$ Tracing is the key step in succeeding at a proprietary claim.

Waters provides a warning on the state of the proprietary remedy in Canada: ${ }^{178}$

.. . These precedents [relating to proprietary remedies] are largely English, they reach back over two hundred years, and they reveal that the English and therefore the Canadian proprietary remedy has developed haphazardly as a result of the character of the forms of action at law and the nature of the residual resort to equity. Its evolution has been uneven, its present form is clearly the result of the random occurrence of litigation, and its proper relation to the personal actions is in large part unexplored. Though it is not undeveloped, and has indeed apparently proved equal to the needs of the judges in Canada, the proprietary remedy is not a showcase for the system of inductive jurisprudence.

\section{Tracing in Equity}

The hallmark of tracing in equity is that the plaintiff must prove that the defendant was in a fiduciary or a trust position in relation to the plaintiff. A fiduciary or a trustee must keep the beneficiary's money or property separate from its own, which act facilitates tracing. ${ }^{177}$

As circular as it may seem, there is also authority for the view that funds cannot be traced if no separate account was in fact established, even if there was a duty to so do, ${ }^{178}$ although the preferred view is that such an omission constitutes a breach of the fiduciary obligation, and does not impugn the existence of a fiduciary relationship nor prevent tracing: 179

The only use of looking at the facts to see whether in the particular case he has kept the money as a separate fund is to see whether he has recognized his obligation, the obligation itself being the essential thing. [emphasis added]

This apparent conflict over the existence of a fiduciary relationship with a breach of that relationship may result from confusion over the principle that "initially there was separate property in which the claimant had a title, and that property should remain identifiable (or accountable as the courts sometimes say) in the defendant's hands". ${ }^{180}$ The existence of a separate and sufficient account goes to the probability that tracing will be successful, not to the availability of the process of tracing, although this distinction may prove to be a moot point in practice.

175. Supran. 1 at 489 ; supran. 55 at 362 to 363 ; supran. 15 at 882.

176. Supran. 55 at 881 .

177. Supran. 143 at 40; supra n. 55 at 889; supran. 133 at 77 to 78.

178. Re Christie Grant (1922) 3 W.W.R. 1161 (Man. C.A.), discussed, supra n. 55 at 884; see also supra n. 133 at 76 to 78 , where the fiduciary relationship was "lost" because it was commingled, contrary to the express obligation.

179. Supra n. 115 at 521; H.E.P.C. Ontario, supra n. 152 at 555. 
Waters takes the position that the availability of tracing in equity and the concept of a constructive trust are not interdependent, though such concepts have been associated over time. Thus, tracing can occur without there being a constructive trust, as other fiduciary relationships will suffice. ${ }^{187}$

For the sake of brevity, several of the fundamental and relevant principles or characteristics of equitable tracing are summarized from the works of Waters, and Goff and Jones, as follows: ${ }^{182}$

1. The equitable tracing remedy is an equitable charge or lien on the property, the converted property or a fund. It is not clear if the amount of the charge or lien includes only the principal, or interest or profit as well. ${ }^{183}$ The non-operator claimant would seek a lien or charge on the monies held by the operator or on the property bought therefrom.

2. Funds cannot be traced if they have been used to pay the debts of the wrongdoer or any subsequent holder, because the creditor is a bona fide purchaser for value without notice. ${ }^{184}$ Indeed, tracing and the recovery of money or property is impossible if any bona fide purchaser for value without notice holds the money or property. ${ }^{185}$ This is a critical factor, and it is often a bar to tracing and to any equitable proprietary remedy.

3. If the non-operator's money is placed in the operator's gencral, mixed bank account (that is, if it is not placed in a separate, trust account) and the bank is without notice of the operator/nonoperator relationship in respect of the money, the bank is entitled to set off the account balance against the debt owing to the bank by the operator. ${ }^{188}$ The claimant may be subrogated to the rights of the bank, but this would only give rise to a (futile) personal action if the fiduciary was insolvent. ${ }^{187}$ Canadian courts are not quick to impute constructive notice of a fiduciary relationship on a bank, because to do so without strong evidence would be unreasonable, given mercantile trade and banking practicalities. ${ }^{188}$ Hence, in the absence of actual notice, it is questionable if an action for fraudulent preference would lie against the bank or other bona fide purchasers for value without notice.

The significance is that, even if an operator is obliged to keep the non-operator's funds separate and in trust, equitable tracing and recovery will not be possible if a bona fide purchaser for value

180. Supran. 55 at 882.

181. Id. at 362.

182. Id.; supra n. 143.

183. Supra n. 55 at 36, 37, 51, 52, and 883 to 884 . The authorities distinguish between liens and charges.

184. Id. at 887; supra $\mathrm{n} .143$ at 50.

185. Id.

186. 1. F. G. Baxter, The Law of Banking (1st ed. 1981) 29 to 37, and "Bank Accounts Under Trust" (August 1983) National Banking Law Review 75.

187. Supra n. 55 at 880, n. 1; and supran. 143 at 55.

188. M.A. Hanna Co. v. Provincial Bank of Canada [1935] I D.L.R. 545 (S.C.C.); supra n. 186; and supra n. 143 at 501 and 502. 
without notice comes into possession of the funds or of the property purchased therefrom as a result of a breach of trust or otherwise.

4. The property to be traced must be "definite and in full ownership", not a right under a purchase contract, wherein the defendant itself is likely to receive nothing. ${ }^{189}$ Thus, in the oil and gas context, one must ensure that the property, including money, is owned by the claimant at the time and is not simply a right to claim ownership in the future. This may create problems for a non-operator which holds a gross overriding royalty or a net profits interest which are not interests in land. In these circumstances, the production of oil or gas cannot be traced into money, as the holder of the interest has no ownership of the oil or gas sold. The holder may only own a right to a share of proceeds or profits from the sale of production.

5. The availability of tracing is not dependent upon the morality involved in the disposition of the property or money. Tracing is possible whether the fiduciary was negligent, dishonest or innocent. 190

6. The courts have set hazy limits on the extent to which identification can be implemented. It may be, as Waters supposes, that: ${ }^{191}$

Perhaps there is also the element that once trust property has been distributed in very small amounts among a large number of third parties, the practicalities of tracing are effectively gone, and the idea of a continuing identity is therefore also gone.

7. A cestui que trust or other owner of money held by a fiduciary may obtain a charge or lien on a mixed fund, provided it can trace the claimed money to the mixed fund. However, the charge or lien on the mixed fund "only extends to the smallest balance to the credit of the mixed fund after payment in of the trust funds" ${ }^{192} \mathrm{~A}$ beneficiary will therefore have a difficult time recovering its money from a widely fluctuating, mixed account which periodically has low balances or is overdrawn.

8. In respect of monies deposited in an ongoing trust or separate account (i.e., monies are not mixed with the fiduciary's monies), a rule of equity has developed which frequently results in "rough justice" for the account beneficiaries. This rule is known as "the Rule in Clayton's Case", and has been summarized as follows by Pennell J., in an unreported Ontario case which deals with the allocation of remaining trust funds from a lawyer's trust account: ${ }^{193}$

.. the rule in Clayton's Case DeVaynes v. Noble (1816) 1 Mer. 57235 E.R. 767 is the governing principle. According to this rule, where sums are paid into and drawn out from time to time on a single running account, if there is no express intention to the con. trary [sic] and no special circumstances from which such an intention can be implied, the accounts rendered are evidence that the payments in on one side are appropriated to the payments out on the other side in the order in which they take place; i.e., the first item on the debit side is discharged or reduced by the first item on the credit side. By this rule the beneficiaries of the trust deposits are entitled to share in inverse order to the time deposits were made. It affords some temporal corroboration of the precept "the last shall be first".

189. Supran. 55 at 886, citing Costev. McLaws [1925] 2 W.W.R. 131, 133 to 134 (Alta. C.A.).

190. Supra n. 143 at 49, citing In Re Hallett's Estate(1879) 13 Ch. D. 696, 709.

191. Supra n. 55 at 888.

192. Re Wineberg (1959) 14 C.B.R. 182. (Ont. S.C.).

193. Re Delaney (1981) (unreported) (Ont. S.C.) at 3. 
Pennell J. reviewed the claimant's argument that the rule in Clayton's Case should not be applied due to the intrinsic inequity it would cause:199

... the argument against the application of the rule in Clayton's Case is to this effect: where the evidence indicates that the manipulations of the trust account resulted in a series of transactions where one client's deposit was used to pay off prior indebtedness to another client, then the last client to deposit money should not be placed in a preferred position; all former clients should be treated equally sharing any available trust funds and having recourse to the Law Society's Compensation Fund for the deficiency. Counsel, however, following an admittedly extensive search, were unable to refer the court to any specific cases where Clayton's rule had not been applied in circumstances analogous to the present case.

The judgment goes on to reveal His Lordship's discomfort in being required to apply this arbitrary rule of equity on the facts, a reminder that equitable actions do not always yield "equitable" or fair results to all concerned: ${ }^{98}$

I am impelled to the belief that the rule in Clayton's Case controls the case at hand. True, of course, the operation of the rule may work some odd and harsh results. If effect be given to this judgment, I can appreciate the feelings of grievance that Mr. and Mrs. Hykawy and Riviera Motel will have. But I have no jurisdiction to make an order of entitlement as a matter of fairness or "equity" in the non-technical sense. It is the province of a court to apply the law, not to make it. Clayton's Case is not modest in its judicial progeny; it is well sustained by modern authority. In Bailey v. Jellet (1884) 9 O.A.R. 187, the Ontario Court of Appeal applied the rule to determine the respective interests of two competing beneficiaries in the proceeds of an insolvent and deceased solicitor's trust account where there was a deficiency; see also Re C.A. Macdonald \& Co. (1947), 28 C.B.R. 262. . . . I add a concluding observation, though I cannot tell whether it will be useful. To use borrowed language, $I$ find it difficult to resist the argu. ment "that it would have been preferable, if, instead of juggling with the accidental time sequence of events, the court has proportioned the loss between the clients according to the amounts due them respectively': Waters, Law of Trusts in Canada p. 895. At the behest of counsel for the respondents Hykawy, I transmit his plea that the Law Society seek legislative action that would confer upon them a discretion in allocating remaining trust assets rather than being compelled to apply the inflexible formula sustained by this court; 1 think he is entitled to have his plea plainly published. Whether such a discretion would be sufficient answer to the admonition that "hard cases make a shipwreck of the law" is not for me to say.

9. Though tracing in equity is thwarted by the intervention of a bona fide purchaser for value without notice, it is not so thwarted by an innocent volunteer. A claimant can recover its money or property from an innocent volunteer so long as "some equitable proprietary interest" has been created and attaches to the money or property in the volunteer's hands. ${ }^{193}$

A court will have a great deal of trouble tracing money through a general, mixed account which undergoes thousands of debit and credit transactions in a given period. When it comes to the tracing of money through a mixed account for the benefit of competing trust beneficiaries, there are a myriad of rules and doctrines which operate to deny or facilitate tracing. ${ }^{197}$

194. Id. at 5.

195. Id. at 6.

196. Supra n. SS at 897; and supra n. 143 at 52 and 53 . It is not clear precisely what "some equitable proprietary interest" means in this context.

197. As the facts of each case will necessarily affect the application of these difficult rules, no attempt will be made to review them in this paper. 
The detailed rules and exceptions to the doctrine of equitable tracing are well presented in Waters and Goff and Jones. ${ }^{198}$ Even without the intervention of a bank or a bona fide purchaser, a non-operator is not guaranteed the full recovery of its money from an operator, because the remaining attachable funds of the operator at the time of the claim will likely be insufficient to satisfy all or any claimants.

Relating the above principles to the operator/non-operator situation, the equitable doctrine of tracing may give rise to an effective proprietary remedy if, at a minimum, all of the following requirements are met:

1. a fiduciary relationship exists;

2. the money claimed is "definitely owned" by the non-operator and such money was originally its own, distinct property;

3. the fund or property in relation to which a charge or lien is claimed is not claimed or held by a bona fide purchaser for value without notice;

4. the money claimed or the money's worth of property is ascertainable or identifiable, on the facts of the case, in the possession of the eventual holder; and

5. the fund or property claimed is, after the application of the appropriate tracing and appropriation rules, adequate to satisfy the non-operator's claim.

Unfortunately, few operator insolvencies will come close to satisfying these requirements. Unless other effective remedies are available, the non-operator of an insolvent operator will be an unsecured creditor which is likely to receive "cents on the dollar" in a bankruptcy. ${ }^{199}$

\section{Tracing at Common Law}

The doctrine of tracing, or "following", at common law is invoked for the same reasons as is equitable tracing, namely, to follow property or money to the holder and to return same to the rightful owner. As was the case for equitable tracing, above, this discussion relies upon the secondary authorities, such as texts and articles, instead of attempting to reconcile every leading case in the area.

It is useful at the beginning to contrast the common law remedies and tracing with equitable remedies and tracing. To pursue a common law remedy, an action must be founded in tort or contract or at least upon a relationship of accountor and accountee. Actions at common law are actions in personam or personal actions, whereas equity deals with the property for a remedy against the world. ${ }^{200}$ In common law tracing, it is not necessary to establish a fiduciary relationship. ${ }^{201}$ Common law remedies

198. Supra n. 55 at 883-890; and supra n. 143.

199. Where there is an ongoing receivership, the non-operator may only lose those monies which are in the operator's hands at the time the receiver takes over. Once the receiver is in place. it will tend to administer the affairs as would the operator, i.e., reviewing and paying out the non-opetator's money in due course: see, e.g. Kerr on Receivers at 130, 131 and 282 . In the long run, the appointment of a receiver may be a boon to the non-operator, because it may formalize the operator's obligations.

200. Supra n. 55 at 882 and 883; and supran. 143 at 44 and 48.

201. Supran. 1 at 479. 
also survive the destruction or loss of the res, or property. ${ }^{202}$ Another difference between equitable and common law tracing relates to the conversion of the property into a new form. The rule in equity is that: ${ }^{203}$

In equity the right to trace property into a new form where the change was unauthorized depends upon an adoption by the principal of the act of his agent. That is necessarily so. The agent is regarded as a fiduciary; his position is equated with that of a trustee; and in a trust proper a breach of trust can only be waived by consent of all the beneficiaries.

The doctrine in common law has been expressed in this way:204

To "trace" at common law means no more than to identify property, in a changed form and in new hands, in order to found a personal action in support of a proprietary right.

The remedies exploited in common law include conversion, detinue, replevin, trover and money had and received. Each remedy has been associated with tangible chattels or things, but as Scott goes to great pains to illustrate, there are good reasons for the application of certain remedies to money or bills of exchange (which are chattels before being converted to bank deposits). ${ }^{205}$

Historically, the problems perceived with common law tracing as an effectual method of recovering money in its various forms have been described as follows:

1. common law remedies required title to the chattel before tracing could be successful, and money converted to a bank deposit broke the chain of title; ${ }^{206}$

2. common law actions did not recognize equitable interests, such as that of a beneficiary under an express trust. A bona fide purchaser for value without notice, such as the insolvent operator's bank, would defeat a common law action, because such a purchaser acquires legal title to the money, and 207

3. since there were no common law remedies which dealt with a mixed fund or with property which included the claimed money, no action was possible where the money was converted into other property or mixed with other funds. ${ }^{208}$

If these problems are still valid, tracing in common law is virtually impossible in the operator/non-operator situation, because equitable interests and the conversion of money into mixed bank accounts are in the normal course of the resource business. Why, then, are common law tracing and remedies worth a second look? It is because there are persuasive arguments that certain of such remedies have been overlooked and undervalued. In some ways, these remedies are superior to those available in equity. The grounds for this optimism arise from the forceful and sardonic article written almost 20 years ago by Michael Scott, ${ }^{209}$ and to a lesser extent, from the analysis in Goff and Jones. ${ }^{210}$

202. Id. at 463 and 479.

203. Id. at 479.

204. Id. at 489.

205. Id. at 47010480 .

206. Supra n. 143 at 46.

207. Supran. 143 at 46; and supran. 51 at 883.

208. Supra n. 51 at 882; and supran. 143 at 35.

209. Supran. 1.

210. Supran. 143. 
Scott quotes Lord Denning, M.R., in respect of the action for money had and received:211

The action for money had and received was and is an effective remedy for the recovery of money. Wherever money was wrongfully taken from the true owner, this action lay to recover it back. It applied to money in all its tangible forms, such as coins or banknotes which the owner had in his possession, or cheques which he had payable to himself or bearer. He might be deprived of such money by thieves or forgers, by fraudulent agents or merely by losing it. It might change its form from coins to cash at the bank, or from cheques to notes, or in any way whatsoever. It might come into the hands of persons innocent of any fraud. Nevertheless, so long as it could be traced, then whatever its form and into whatsoever hands it came, the plaintiff to whom it belonged had this action to recover it back unless and until it reached the hands of one who received it in good faith and for value and without notice of the misappropriation.

As well, Scott examines the roles of a receiver, a bailiff and an accountor to illustrate that: ${ }^{212}$

(a) common law tracing need not be premised upon an action in contract; and

(b) contrary to the conventional wisdom discussed above, common law tracing can be available with respect to a fluctuating, mixed fund of money.

Scott points out that a bona fide purchaser defence might not succeed in a common law action for conversion, as the plaintiff can always waive the tort of conversion and sue for money had and received. ${ }^{213}$ In other words, the bona fide purchaser defence may defeat a conversion action, but not an action for money had and received. Scott also refutes the proposition that detinue will not lie for money, by the argument that detinue is based upon the defendant's wrongful act, that is, the refusal to return the goods. The inability to distinguish or identify the property is thought to be irrelevant to the availability of the action. ${ }^{214}$ Both Scott and Goff and Jones conclude that a bona fide purchaser defence will not defeat an action for money had and received. ${ }^{215}$

Atkin L.J., has explained why the common law should not be halted "outside the banker's door":216

I notice that in Sinclair v. Brougham Lord Haldane L.C. in dealing with this decision says: "Lord Ellenborough laid down, as a limit to this proposition, that if the money had become incapable of being traced, as, for instance, when it had been paid into the broker's general account with his banker, the principal had no remedy excepting to prove as a creditor for money had and received," and proceeds to say "you can, even at law, follow, but only so long as the relation of debtor and creditor has not superseded the right in rem." The words above "as for instance" et seq. do not represent and doubtless do not purport to represent Lord Ellenborough's actual words; and I venture to doubt whether the common law ever so restricted the right as to hold that the money became incapable of being traced, merely because paid into the broker's general account with his banker. The question always was, Had the means of ascertainment failed? But if in 1815 the common law halted outside the bankers' door, by 1879 equity had

211. Supran. 1 at 469.

212. Id. at 471 to 472.

213. Id. at 477.

214. Id. at 473 to 474.

215. Supra n. 143 at 46 to 48, citing Banque Belge Pour L'Etrangerv. Hambrouck et al. [1921] 1 K.B. 321 and Taylor v. Plumer(1815) 3 M. \& S. S62, 105 E.R. 721; and supra n. 1 at 481 to 489. citing Banque Belge, supra, and Taylor, supra, as well as Scott v. Surman (1742) Willes 400, 125 E.R. 1235.

216. Banque Belge, id. n. 215 at 335-336. 
had the courage to lift the latch, walk in and examine the books: In Re Hallett's Estate. I see no reason why the means of ascertainment so provided should not now be available both for common law and equity proceedings. If, following the principles laid down in In Re Hallett's Estate it can be ascertained either that the money in the bank. or the commodity which it has bought, is "the product of, or substitute for, the original thing." then it still follows "the nature of the thing itself." On these principles it would follow that as the money paid into the bank can be identified as the product of the original money, the plaintiffs have the common law right to claim it, and can sue for money had and received. In the present case less difficulty than usual is experienced in tracing the descent of the money, for substantially no other money has ever been mixed with the proceeds of the fraud. (footnotes omitted]

There are solid grounds for the view that the perceived shortcomings of the common law tracing approach should be reevaluated. Common law tracing may be a shrewd course of action for a non-operator who is unable to prove a fiduciary relationship with his operator or who is faced with a bona fide purchaser defence. Scott shall have the last words in this regard:217

... where money or other property belonging to A can be identified as having passed into the hands of $B$ and thence into the hands of a third party $C$, this may give rise to a personal right of action against $C$ in conversion or in detinue or for money had and received; and in the specific case of an insolvency of $B$, this action against $C$ (whether he be the banker of $B$, the trustee in bankruptcy of $B$, one to whom $B$ has consigned the goods of $A$, or the personal representative of $B$, etc.) will enable $A$ to recover in full as against the other creditors of $B$, and 50 to recover all he would have done by a tracing order in equity. Whatever deficiencies the common law remedy may have, it is in three respects wider than that of equity. It does not depend upon a fiduciary relationship; it does not depend upon any adoption by the plaintiff of an agent's acts; and since it operates strictly in personam it does not depend upon the continued existence or identifiability of the res. [emphasis added]

\section{CONCLUSIONS}

The examination of the CAPL form and the production sale agreements reveals that a non-operator may be merely an unsecured creditor of an insolvent operator, because the operator may not be a fiduciary or a trustee in respect of the non-operator's money. A review of the "true relationship" of these parties yields no substantially different result. The critical deficiency in the non-operator/operator relationship is the express or implied authority given to the operator to commingle the non-operator's money with the operator's other funds.

The failure to prove a fiduciary or trustee relationship appears to be an absolute bar to equitable tracing.

The non-operator under a C\&O Agreement may be able to invoke the remedies available to a cestui que trust, but the effectiveness of recovery might be hampered by a breach of the trust, by an inability to trace the funds, or by the inadequacy of funds or property to satisfy the claim. Under provincial legislation not yet put into force, a non-operator whose production is being sold to the APMC through the project operator would be afforded a higher degree of protection than that which currently exists. The salutory provisions are now in limbo, awaiting proclamation when the Government of Alberta determines it appropriate.

In the event that the prerequisites to the equitable doctrine of tracing are met, the effectiveness of the remedies is uncertain due to the complex

217. Supran. 1 at 489. 
principles governing the appropriation of funds. The defence of bona fide purchaser is a bar to a non-operator's equitable tracing action. As most operator insolvencies will involve banks and bank accounts, this bar to the equitable tracing remedies may be the most significant.

The common law doctrine of tracing has suffered some inattention and "bad press", although it has developed in a parallel fashion to the equitable tracing doctrine. ${ }^{218}$ Scott, for one, has examined the common law remedies, especially actions for detinue and for money had and received. He has demonstrated that common law tracing may be the preferred alternative where:

(a) a fiduciary relationship cannot be proven; or

(b) the property to be followed has "gone", either to a bona fide purchaser or into thin air (i.e., identification is impossible or the property has been destroyed).

Given the limitations inherent to equitable tracing, these arguments for common law tracing are "good news" for the non-operator.

On the assumption that no non-operator wants to place itself before the courts for the unpredictable adjudication of these convoluted tracing principles and remedies, a few "modest" suggestions will be offered as the means of lessening the exposure of the non-operator in the event of an operator insolvency.

\section{A FEW MODEST SUGGESTIONS}

\section{A. OVERVIEW}

These suggestions fall into three broad categories:

1. contractual approaches relating to the agreements entered into between the operators and non-operators;

2. operational actions, meaning the conduct of the parties, inter se and with third parties; and

3. legislative approaches.

\section{B. CONTRACTUAL METHODS}

A non-operator who is party to an existing operating agreement, or who is or about to enter into one, may benefit by implementing these suggestions.

1. The strongest position is to require a provision in the operating agreement which expressly and clearly obliges the operator to establish and maintain a separate, trust bank account for the project, through which all project monies, including production proceeds, must flow. This would entail an express negation of Clause 5.07 of the 1981 CAPL, which provision allows commingling. Ideally, this trust account should be located at a financial institution other than the principal lender of the operator. On the opening of the account, the trust nature of the account should be communicated in writing to the financial institution, perhaps with a copy of the relevant agreement. If an account already exists for a

218. Id. at 464; and supran. 55 at 879 to 881 . 
project, it might be preferable to open a new account in the manner described, rather than attempt to re-characterize the existing account over the financial institution's objections. The aim is to put the financial institution on actual notice of the trust, so that it cannot treat the balance in the account as a credit of the operator, against which it can set-off the operator's debts. Also, in the event that the financial institution acts imprudently, the non-operator may be able to avail itself of technical trust arguments against the financial institution. ${ }^{219}$

2. For a large project, it may be worthwhile to consider the Boyer suggestion of a "zero accounting system", whereby each party opens its own account, but all accounts are at one financial institution. 220 The financial institution is instructed by the operator to debit any cash call against each party in the specified proportions at the close of each banking day. The cash call is initiated by a debit to the operator's project account. At the end of each banking day, the operator project account balance is zero. In this way, the operator is kept whole; the non-operator, not the operator, earns interest on its money until it is called for, and the problems associated with the commingling of funds would be ameliorated. This idea does not address the issue of production sale proceeds, so a separate trust account, as described above in Item 1, may still be needed. Alternatively, the operator's project account might initially receive revenue, but the financial institution would be instructed to credit such amounts immediately and proportionately to each party's separate account. It is submitted that this alternative only goes to the "comfort level" of the non-operators, as the theoretical exposure probably remains: for example, if the operator breaches the trust, the non-operator must still seek to trace the funds.

3. Where separate trust accounts for each project would be impractical or too costly, an alternative arrangement is suggested. By analogy to the legal profession's trust accounts, the operator could set up one trust account for all monies not owned by it. As with a law firm's trust account, the general trust ledger would show which parties were entitled to the amount in the account. The account would be designated as a trust account to the financial institution, but the financial institution could not, practically speaking, be put on actual notice of the interests of every beneficiary of the account. This alternative may be only slightly preferable to current banking arrangements, as there is still no mechanism for ensuring that the operator: (a) deposits the non-operator's money received from third parties into the trust account; and (b) does not breach the trust by defalcating trust monies for its own purposes.

4. It is important to ensure that all project monies and procedures are governed by a written operating agreement which incorporates the separate trust account concept, in order to avoid unpredictable in-

219. Supran. 186 at 31 to 37; and supra n. 143 at 501 .

220. Boyer, supra $n$. 7 at 89 . For a forceful example of the effectiveness of the separate account idea, see Carreras Rothmans Ltd. v. Freeman Mathews Treasure Lid. et al. [1984] 3 W.L.R. 1016 (Ch.). 
terpretation of the agreements by the courts. Such implied contracts may not include the essential fiduciary duties and obligations, nor reflect the real intention of the parties.

5. Obtaining legal title to the project lands or interests in order to put third parties on actual notice of the non-operator's interests is useful, as is being properly novated into all operative agreements. Note that the Alberta courts have carefully distinguished an interest held in trust from the proceeds of production being held in trust. ${ }^{221}$ Nevertheless, if a non-operator is forced to sue an operator in a tracing action, it cannot hurt to replace equitable ownership with legal ownership and rights of action. Alternatively, a "nonrecognized party" should at least impose a trust obligation on the party through which it participates.

6. Remunerating the operator with a fee, which incorporates a worthwhile profit element, for its services, as an inducement and reward, is a radical concept, but one worth considering.

7. Operators could be bonded against defalcation or insolvency, but this idea could be expensive and difficult to implement.

\section{OPERATIONAL ACTIONS}

The kinds of actions a non-operator can take to protect itself are selfapparent:

1. Appoint a financially stalwart operator, the corollary of which is, fire an insolvent operator; ${ }^{222}$

2. Monitor the status of the operator and be aware of such danger signs of an impending insolvency as slow remittances, frequent overcharging and the accumulation of claims and liens on the project property and other property;

3. Become knowledgeable about such aspects of the project accounts as the normal quantum of production receipts, the timing of receipts and disbursements, prices, and third party involvement. The standard operating agreement allows the non-operator a reasonable degree of access to the books and records of the project, ${ }^{223}$ and this access should be exploited at frequent and random intervals to the extent reasonable in the circumstances;

4. Take advantage of the non-operator's right of access to the physical property to confirm the existence of the property purchased or services provided on its behalf by the operator; and

5. Utilize the common law right of set-off by not advancing more funds when the operator is in possession of production proceeds or a sufficient operating balance. This technique does not cure the problem, but it tends to reduce the exposure of the non-operator at any one time. The non-operator must be cautious not to breach the relevant agreement in the process, and thereby avail the operator of

221. Act Oils Lid., supra n. 124.

222. It may be that the insolvent operator is to be removed automatically: see, e.8., supra $\mathrm{n} .2$, 1981 CAPL. Clause 202. Of course, a project cannot be left without an operator by means of an automatic mechanism.

223. Supra Part II.B.2. 
several remedies against the non-operator. Further, it may be somewhat risky to use a set-off which has an effect over several agreements and obligations in respect of diverse projects. Set-off is apparently prevalent now between operators and non-operators which have numerous or large projects with comparable money flows in both directions. However, the set-off is obviously of limited use in situations where the non-operator is usually receiving, or entitled to receive, substantial funds from the operator, but not vice versa.

\section{LEGISLATIVE SUGGESTIONS}

It is submitted that the Government of Alberta should consider proclaiming paragraphs 21.1(3)(b) and (c) of the Petroleum Marketing Act ${ }^{224}$ if it remains concerned about the financial vulnerability of the nonoperators, particularly the many small, independent non-operators. Although these provisions are not a panacea, they would, at the least, clarify the operator's obligations in relation to the sale of oil from Alberta Crown leases.

Whether or not any government should go further to protect one group of contracting parties from another is a controversial public policy issue, particularly where both groups are perfectly free to address the issues by written agreement if they so desire.

It is appreciated that many, if not all, of the suggestions herein are major departures from conventional practice and entail a cost to implement. Until the Canadian law of constructive trusts, unjust enrichment, and restitution evolves much further, these measures may be the price a nonoperator must bear to safeguard its money in the hands of the operator. 